\title{
Review of Cretaceous sauropod dinosaurs from Central Asia
}

\author{
Alexander Averianov ${ }^{a, b,{ }^{*}}$ and Hans-Dieter Sues ${ }^{c}$ \\ a Zoological Institute, Russian Academy of Sciences, Universitetskaya nab. 1, 199034 \\ Saint Petersburg, Russia \\ ${ }^{\mathrm{b}}$ Department of Sedimentary Geology, Geological Faculty, Saint Petersburg State \\ University, 16 Liniya VO 29, 199178 Saint Petersburg, Russia \\ ${ }^{\mathrm{c}}$ Department of Paleobiology, National Museum of Natural History, Smithsonian \\ Institution, MRC 121, P.O. Box 37012, Washington, DC 20013-7012, USA \\ * Corresponding author \\ E-mail addresses: dzharakuduk@mail.ru (A. Averianov), suesh@si.edu (H.-D. Sues).
}

\section{Abstract}

There are 24 known localities for skeletal remains of sauropod dinosaurs in the republics of Central Asia (Kazakhstan, Kyrgyzstan, Tajikistan, and Uzbekistan).

Sauropod remains are very rare at all these localities and represented usually only by isolated teeth. Only narrow-crowned teeth are known from the Cretaceous of Central Asia. The oldest record of such teeth is from the Aptian Sultanbobo Formation of Uzbekistan. Exposures of the Turonian Bissekty Formation at the most productive vertebrate locality in the region, Dzharakuduk in Uzbekistan, has yielded many isolated teeth and a few skeletal remains that can be attributed to a non-lithostrotian titanosaur. Similar narrow-crowned, cylindrical teeth from Cenomanian- to Coniacian-age strata in the Kyzylkum Desert, Uzbekistan, may belong to a closely related taxon. Another taxon, with teeth that are pentagonal in cross-section, is known from the Santonian Yalovach and Bostobe formations of Tajikistan and western Kazakhstan, respectively. A femur reported from the Santonian Syuksyuk Formation of southern Kazakhstan possibly belongs to a lithostrotian titanosaur. The change in tooth structure at the ConiacianSantonian boundary in the region possibly suggests replacement of non-lithostrotian titanosaurs by lithostrotians. The titanosaur from the Bissekty Formation is similar to Dongyangosaurus sinensis from the Cenomanian-Turonian of Zhejiang (China) in the extensive pneumatization of the neural arch on the anterior caudal vertebrae with several fossae. It also resembles Baotianmansaurus henanensis from the Cenomanian of Henan (China) in the possession of very short anterior caudal centra. These three taxa possibly represent an as yet formally unrecognized endemic clade of Asian nonlithostrotian titanosaurs.

Keywords: Sauropoda, Cretaceous, Kazakhstan, Kyrgyzstan, Tajikistan, Uzbekistan

\section{Introduction}

Sauropod dinosaurs, large to gigantic, quadrupedal herbivores, dominated in the Jurassic and Early Cretaceous ecosystems worldwide (Mclntosh, 1990; Upchurch et al., 2004; Wilson, 2005a). During the Late Cretaceous, one surviving clade of sauropods, Titanosauria, flourished in the Southern continents but was fairly common in parts of the Northern Hemisphere, although there the dominance among plant-eating dinosaurs shifted to ornithopods and ceratopsians. In recent decades, a number of Cretaceous titanosaurian or titanosauriform sauropods, usually documented by partial skeletons, have been described from East Asia, mostly China (D'Emic, 2012; Mannion et al., 2013). By contrast, sauropod remains from the Cretaceous of Central Asia are quite 
rare and represented mostly by isolated bones, bone fragments, and teeth (Nesov, 1995; Maryańska, 2000). Moreover, few of these specimens have ever been described (Sues et al., 2015). However, they are of interest because they date from the otherwise poorly known Cenomanian-Santonian interval of sauropod evolution (Mannion et al., 2011: fig. 5). In this report, we summarize data for 24 localities with Cretaceous sauropod fossils in Kazakhstan, Kyrgyzstan, Tajikistan, and Uzbekistan (Fig. 1) and describe all specimens that can still be located in collections.

Nesov (1995) published the first review of sauropod records from the Cretaceous of Central Asia. Some identifications of indeterminate sauropods were based on bones or bone fragments. He assigned all narrow-crowned, 'pencil-shaped' teeth to indeterminate diplodocids or titanosaurids. Nesov (1995: p. 89) mentioned a metapodial and another limb-bone fragment of a sauropod from the lower Cenomanian locality Krasnaya gora [Red Mountain] in the central Kyzylkum Desert of Uzbekistan. This identification was possibly based on the distal fragment of a third metatarsal of indeterminate hadrosauroid ornithopod (ZIN PH 1906/16) because no other dinosaurian metapodials can be identified in the collections from this locality. Thus, this occurrence is not included in our review.

\subsection{Institutional abbreviations}

CCMGE, Chernyshev's Central Museum of Geological Exploration, Saint Petersburg, Russia; IZANUZ, Institute of Zoology, Uzbek Academy of Sciences, Tashkent, Uzbekistan; USNM, Department of Paleobiology, National Museum of Natural History, Smithsonian Institution, Washington, D.C., U.S.A.; ZIN PH, Paleoherpetological Collection, Zoological Institute, Russian Academy of Sciences, Saint Petersburg, Russia.

\subsection{Measurements}

Teeth: LLD, labiolingual diameter; MDD, mesiodistal diameter. Tooth measurements and wear facet terminology follows Averianov and Sues (2016). SI is the slenderness index, which is calculated by dividing the height of the tooth crown by the mesiodistal diameter of the crown (Upchurch, 1998).

Vertebrae: $\mathrm{ACH}$, anterior height of centrum; $\mathrm{ACW}$, anterior width of centrum; $\mathrm{CL}$, centrum length (ventral); $\mathrm{PCH}$, posterior height of centrum; PCW, posterior centrum width.

All measurements are in millimeters.

\section{Review of sauropod localities}

\subsection{Karakul'}

Geographic position. NNE coast of Karakul' Lake, close to the Zengebobo Ridge, southwestern Kyzylkum Desert, Karakalpakistan, Uzbekistan.

Stratigraphy. Sultanbobo Formation, upper Aptian (Nesov, 1997).

Material. Titanosauria indet.: one tooth fragment (ZIN PH 2431/16; Fig. 2A, B).

Description. The crown of this apparently lower tooth is lingually recurved and almost round in cross-section, with LLD (5.3) slightly greater than MDD (5.1). There are four irregular wear facets all around the crown, the largest of which is on the convex (labial) side (Fig. 2B). The enamel is smooth. 
Comments. ZIN PH 2431/16 is the only record of dinosaurs from the Karakul' locality, which otherwise has only yielded remains of marine vertebrates (Mertiniene et al., 1994; Nesov, 1995).

\subsection{Khodzhakul}

Geographic position. Escarpment N of the dried-up Khodzhakul Lake, southwestern Kyzylkum Desert, Karakalpakistan, Uzbekistan.

Stratigraphy. Lower or middle part of Khodzhakul Formation, uppermost Albian(?) or lower Cenomanian (Nesov, 1997).

Material. Titanosauria indet.: 12 tooth fragments, seven with preserved apices of the tooth crowns.

Description. Among the tooth crowns preserving the apex there is an unerupted replacement tooth lacking the root and enamel. One apparently lower tooth has a single lateral wear facet (ZIN PH 2428/16; A0L1 wear pattern; Fig. 2F, G). The remaining five specimens are small upper teeth, each with a lingually curved crown and variably developed single elliptical wear facets on the lingual side (A1L0 wear pattern; Fig. 2C-E, $\mathrm{H}, \mathrm{I}$ ). On ZIN PH 2429/16, the wear facet is set at a steep angle and extends down to the root (Fig. 2E). The enamel is either smooth around the perimeter of the crown or smooth in the apical half and covered by fine sculpture in the basal half (ZIN PH 2428/16; Fig. 2F, G). Most tooth crowns bear variably developed apicobasal ridges.

Comments. Nesov (1995) assigned long and slender sauropod teeth from the Khodzhakul locality to Diplodocidae or Titanosauridae. On the label accompanying the specimens, he indicated that small faceted sauropod teeth from Khodzhakul possibly belong to a distinct taxon. It is not clear whether this character is taxonomically important or merely represents ontogenetic variation.

\subsection{Sheikhdzheili}

Geographic position. Northern end of the Sheikhdzheili Range, southwestern Kyzylkum Desert, Karakalpakistan, Uzbekistan.

Stratigraphy. Upper part of Khodzhakul Formation, lower Cenomanian (Nesov, 1997).

Material. Titanosauria indet.: 26 tooth fragments, 12 with preserved apices.

Description. Among the tooth crowns with preserved apical ends, one tooth is unworn and eight teeth each have one apical facet. The A1L0 wear pattern is present on six upper teeth (Fig. 2J-O), and two lower teeth. One tooth crown has an A1L1 wear pattern, one lower tooth an A2L0 wear pattern, and one lower tooth has an A2L2 wear pattern (ZIN PH 2426/16; Fig. 2P-R). The single apical wear facet is symmetrical (in three specimens) or skewed toward the mesial or distal side of the crown (four specimens). On ZIN PH 2424/16, the wear facet is steeply angled and extends beyond the crown-root boundary (Fig. 2J). On the lower tooth ZIN PH 2426/16, the primary apical wear on the labial side is elliptical and much larger than the secondary wear facet on the lingual side (Fig. 2P, R). One of the lateral wear facets is wedge-shaped and tapers basally, not reaching the root (Fig. 2Q). The other lateral wear facet forms a narrow strip extending along the entire height of the crown.

The enamel sculpturing is reduced. On the upper tooth ZIN PH 2425/16, some portions of the labial side of the crown have the texture of crumpled paper whereas most of the lingual side is smooth (Fig. 2M-O). All preserved enamel on the upper tooth ZIN PH 2424/16 has the texture of crumpled paper (Fig. 2J-L). On three upper teeth, including the largest tooth in the sample (ZIN PH 2427/16; MDD=9.7, LLD=8.5), the 
enamel is generally smooth with patches of crumpled texture and with some irregular pits. The enamel is smooth on the lower tooth ZIN PH 2426/16 (Fig. 2P-R).

Comments. Nesov (1995: pl. 3, fig. 10) figured one lower tooth with an apical wear facet (CCMGE 482/12457) and referred long and narrow sauropod teeth from Sheikhdzheili to diplodocid or titanosaurid sauropods. Earlier finds of sauropod teeth from Sheikhdzheili were tentatively referred to Titanosauridae (Nesov, 1988). The sauropod teeth from this locality are indistinguishable from the titanosaurian teeth from the Turonian Bissekty Formation (Dzharakuduk locality) and possibly belong to the same or a closely related taxon.

\subsection{Khodzhakul'sai}

Geographic position. About $1 \mathrm{~km}$ NW from the Sheikhdzheili locality, at the northern extremity of the Sheikhdzheili Range, southwestern Kyzylkum Desert, Karakalpakistan, Uzbekistan. 1997).

Stratigraphy. Upper part of Khodzhakul Formation, lower Cenomanian (Nesov,

Material. Titanosauria indet.: one tooth fragment and one almost complete worn tooth (ZIN PH 2432/16).

Description. ZIN PH 2432/16 is apparently a lower posterior tooth with a rather short straight crown (Fig. 3A-C). The crown is slightly expanded beyond the root and labiolingually flattened, tapering toward the apex $(M D D=2.5 ; L L D=2.0)$. There are two apical and one lateral wear facets (wear pattern A2L1). The primary apical wear facet is on the labial side of the crown. It is elliptical and connects with the large lateral wear facet along half of mesial or distal side. The secondary apical facet is smaller and closer to distal or mesial side. The enamel is smooth.

Comments. Nesov (1995) cited long and slender sauropod teeth from Khodzhakul'sai.

\subsection{Chelpyk}

Geographic position. Isolated hill topped by the ruins of a Khorezm castle, $\mathrm{N}$ of the western end of the Sultan-Uvais Range, southwestern Kyzylkum Desert, Karakalpakistan, Uzbekistan. 1997).

Stratigraphy. Upper part of Khodzhakul Formation, lower Cenomanian (Nesov,

Material. Titanosauria indet.: six tooth fragments (three with apical ends); one complete crown (ZIN PH 2433/16).

Description. ZIN PH 2433/16 is the unworn, unerupted crown of a replacement tooth $(\mathrm{CH}=16.1 ; \mathrm{MDD}=3.2 ; \mathrm{LLD}=2.9$; Fig. 3D, $\mathrm{E})$. The crown is shaped like the blade of an ancient Roman sword (gladius), tapering toward the apex. Most of the enamel is missing. Three presumably lower teeth have wear patterns A0L1 (two specimens) and A1L1 (one specimen). A large tooth fragment (MDD=8.2; $L L D=7.8$ ) has enamel with the texture of crumpled paper. The smaller teeth have smooth enamel.

Comments. Nesov (1995: pl. 3, fig. 11) noted long and slender sauropod teeth from Chelpyk and figured one tooth fragment.

\subsection{Itemir}

Geographic position. $37 \mathrm{~km}$ SW of the Mynbulak settlement, central Kyzylkum Desert, Navoi Viloyat, Uzbekistan.

Stratigraphy. Dzharakuduk Formation, Cenomanian (Nesov, 1997). 
Material. Titanosauria indet: one complete tooth and three tooth fragments (ZIN PH 2434/16).

Description. The largest tooth fragment (MDD=7.5; $D D D=5.6)$ is $\mathrm{D}$-shaped in cross-section and covered by finely wrinkled enamel. Other specimens have smooth enamel. ZIN PH 2434/16 is a small upper tooth with a relatively short crown that is slightly expanded beyond the root and curves lingually (MDD=2.5; LLD=1.9; Fig. $3 \mathrm{~F}-\mathrm{H})$. The single apical wear facet is on the lingual side of the crown. It is steeply angled and large, with two prongs, one in the middle and one near the mesial or distal edge. The small pulp cavity is exposed at the center of wear facet.

Comments. Nesov (1997) and Averianov and Sues (2007) previouly cited the occurrence of sauropod teeth from the Dzharakuduk Formation at Itemir.

\subsection{Karachadalysai}

Geographic position. Ravine on the eastern end of the Sultan-Uvais Range, southwestern Kyzylkum Desert, Karakalpakistan, Uzbekistan.

Stratigraphy. Khodzhakul Formation, upper(?) Cenomanian (Nesov, 1997).

Material. Titanosauria indet.: two tooth fragments.

Description. The upper tooth fragment (ZIN PH 2435/16; MDD=2.7; LLD=2.1) has a lingually curved crown, with an apical wear facet on the lingual side. The crown is hexagonal in cross-section. The enamel is finely wrinkled. The lower tooth (ZIN PH 2436/16; $M D D=3.3 ; ~ L L D=2.6$ ) has a straight crown and an apical wear facet. The crown is oval in cross-section. The enamel is smooth.

Comments. Nesov (1995: p. 123) cited the occurrence of cf. Diplodocidae for this locality.

\subsection{Gul'cha}

Geographic position. Near Gul'cha village, SE of the Fergana Depression, Osh Region, Kyrgyzstan.

Stratigraphy. Lower part of Sharikhan Formation, Cenomanian (Nesov, 1997).

Material. Sauropoda indet.

Comments. G.G. Martinson in 1962 and later A.K. Rozhdestvensky collected sauropod bones at Gul'cha (Rozhdestvensky and Khozatsky, 1967; Rozhdestvensky, 1973; Nesov, 1995; Averianov, 2006).

\subsection{Suzak}

Geographic position. Near Suzak, E part of the Fergana Depression, JalalAbad Region, Kyrgyzstan.

Stratigraphy. Lower part of Sharikhan Formation, Cenomanian (Nesov, 1997).

Material. Sauropoda indet.: partial pelvis with sacrum and femur.

Comments. A.K. Rozhdestvensky excavated these bones in 1964

(Rozhdestvensky and Khozatsky, 1967; Rozhdestvensky, 1973; Nesov, 1995; Averianov, 2006).

\subsection{Kulkuduk}

Geographic position. Bukantau Range near the Kulkuduk settlement, $50 \mathrm{~km} \mathrm{NE}$ of Uchkuduk, central Kyzylkum Desert, Navoi Viloyat, Uzbekistan.

Stratigraphy. Lower part of Bissekty Formation, middle to upper Turonian (Nesov, 1997). 
Material. Sauropoda indet.: unspecified specimens collected by I.M. Abduazimova.

Comments. Nesov (1995) noted sauropod remains for this locality.

\subsection{Dzharakuduk}

Geographic position. Escarpment exposing Cretaceous deposits $32 \mathrm{~km} \mathrm{SW}$ of the Mynbulak settlement, central Kyzylkum Desert, Navoi Viloyat, Uzbekistan.

Stratigraphy. Bissekty Formation, upper Turonian (Archibald et al., 1998).

Material. Titanosauria indet:: partial braincase (CCMGE 628/12457), fragments of vertebrae and limb bones, isolated teeth (housed in the collections of ZIN PH, IZANUZ, and USNM).

Description. ZIN PH 2439/16 is a partially preserved centrum of a dorsal vertebra ( $C L=174$; Fig. 4), which was not mentioned in our previous study on sauropod remains from Dzharakuduk (Sues et al., 2015). The centrum is deeply opisthocoelous and relatively short, with the ratio of centrum length to height of posterior articular surface being about 1.7. Although incomplete, the transverse width of the articular surfaces was distinctly greater than their dorsoventral height. The ventral surface of the centrum is concave anteroposteriorly and convex transversely, without a keel or groove. About three quarters of the centrum are occupied by a large pneumatic chamber (camera), which is divided by a thin median septum (Fig. 4D). The articular ends and lateral portions of the centrum are composed of bone with large cancellous spaces (camellae) that are separated by thin bony lamellae. These cancellous spaces open on the anterior articular surface of the centrum through a pair of large pneumatic foramina positioned closer to the ventral border of the articular surface (Fig. 4A). The right side partially preserves the ventral rim of the pleurocoel (Fig. 4D). The pleurocoel was apparently relatively small.

Comments. Sosedko (1937) referred sauropod caudal vertebrae and humerus from Dzharakuduk to "?Brontosaurus." Efremov (1944: p. 43) noted "very rare and difficult to identify" sauropod bones from Dzharakuduk (= Bissekty in his usage). Rozhdestvensky (1964) claimed that there were no sauropod bones from Dzharakuduk. Nesov (1995) briefly discussed sauropod bones from Dzharakuduk and figured a tooth and an ungual phalanx (1995: pl. 3, fig. 9; pl. 10, fig. 24). Sues et al. (2015) described a partial braincase and several postcranial bones of sauropods from Dzharakuduk. Averianov and Sues (2016) provided a detailed description of isolated sauropod teeth from Dzharakuduk. Nesov (1995: p. 19) estimated the length of the incomplete cervical centrum IZANUZ 335 (Fig. 5A-C) at 38 to $40 \mathrm{~cm}$. However, this fragment represents only about half of the total length of the centrum (Fig. 5D). Thus, this cervical may have been comparable in size to those of Giraffatitan brancai (Janensch, 1950). The extensive pneumatization of the dorsal centra, seen in the adult specimen ZIN PH 2439/16 (Fig. 4), is lacking in juvenile specimens such as USNM 538133 (Sues et al., 2015: fig. 6). The juvenile centra have the camerate structure whereas the adult ones are semicamellate (Wedel, 2003). The absence of definitive sauropod osteoderms among the thousands of vertebrate bones from Dzharakuduk (which include numerous osteoderms of ankylosaurs and crocodyliforms) possibly indicates that the Bissekty taxon is a non-lithostrotian titanosaur.

\subsection{Zenge Kurgan 3}

Geographic position. Right bank of the Amu Darya river between the villages of Bezergen and Kulatau, southwestern Kyzylkum Desert, Khorezm Viloyat, Uzbekistan. 
Stratigraphy. Conglomerate that may be part of the Bissekty Formation, Turonian (Averianov, 2014).

Material. Titanosauria indet.: 10 tooth fragments, one with apical end, and one complete tooth (ZIN PH 2438/16).

Description. Both specimens with preserved apical ends are upper teeth that curved lingually. ZIN PH 2437/16 (MDD=5.7; LLD=5.3; Fig. 3L-N) has two apical facets (wear pattern A2L0). The complete tooth ZIN PH 2438/16 (MDD=2.6; LLD=2.3; Fig. 3IK) has one apical and one lateral facet (wear pattern A1L1). The enamel is smooth on these teeth and most other tooth fragments. Only one tooth fragment has finely wrinkled enamel. ZIN PH 2437/16 has a small oval depression on the mesial or distal side of the crown (Fig. $3 \mathrm{~N}$ ), possibly generated by an overlapping facet.

Comments. Averianov (2014) first reported the presence of sauropods at this locality.

\subsection{Dzhara}

Geographic position. $35 \mathrm{~km} \mathrm{SW}$ of the Mynbulak settlement, at the top of the Dzharakuduk escarpment near Dzhara hill, central Kyzylkum Desert, Navoi Viloyat, Uzbekistan. 1998).

Stratigraphy. Aitym Formation, upper Turonian-Coniacian (Archibald et al.,

Material. Titanosauria indet.: five fragments of small teeth, two with preserved apices.

Description. Both specimens with preserved apices are lower teeth with a straight crown that is round in cross-section. They each have one elliptical apical wear facet (wear pattern A1L0). The enamel is smooth on all tooth fragments.

\subsection{Tyulkili}

Geographic position. An exposure of Cretaceous strata $80 \mathrm{~km} \mathrm{~N}$ of the Dzhusaly railway station, Lower Syr-Darya Uplift, north-eastern Aral Sea region, Kyzylorda Province, Kazakhstan.

Stratigraphy. Zhirkindek Formation, upper Turonian-Coniacian (Averianov et al., 2016). 2/111).

Material. Titanosauria indet.: centrum of a posterior caudal vertebra (ZIN PH

Description. ZIN PH 2/111 is a posterior caudal vertebra lacking its neural arch $(\mathrm{CL}=72.8 ; \mathrm{ACH}=41.1 ; \mathrm{ACW}=40.3 ; \mathrm{PCH}=41.9 ; \mathrm{PCW}=47.0 ;$ Fig. 6$)$. The centrum is amphicoelous, with its posterior articular surface deeper than the anterior one. The anterior articular surface is hexagonal in outline and the posterior articular surface is round. The height and width of the centrum are almost equal anteriorly but the width is greater than the height posteriorly. A shallow ventral groove extends posteriorly between the poorly defined chevron facets. The neural arch has short peduncles and is positioned well forward of the posterior end of the centrum.

Comments. This record of a sauropod dinosaur was not included in a recent review of vertebrates from the Zhirkindek Formation (Averianov et al., 2016). The anterior position of the neural arch is characteristic for Titanosauriformes (Upchurch et al., 2004; Curry Rogers, 2005). In derived titanosaurs (Alamosaurus + Saltasaurini), the middle and posterior caudal vertebrae are procoelous (D'Emic, 2012). However, similar posterior caudals are present in the saltasaurid Opisthocoelicaudia skarzynskii (BorsukBiałynicka, 1977: pl. 6, fig. 3). ZIN PH 2/111 resembles the posterior caudal vertebrae ZIN PH 962/16 from the Bissekty Formation of Uzbekistan (Sues et al., 2015: fig. 8). It 
differs in its more concave anterior articular surface, the lesser degree of constriction of the centrum at mid-length, and the more pronounced ventral groove.

\subsection{Kansai}

Geographic position. Near Kansai village, NE Fergana Depression, Sughd Province, Tajikistan.

Stratigraphy. Upper part of Yalovach Formation, lower Santonian (Nesov, 1997).

Material. Titanosauria indet.: 16 fragments of small teeth, one fragment of a large tooth (ZIN PH 17/66), two complete teeth.

Description. The nearly complete large tooth ZIN PH 18/66 (MDD=6.9; LLD=5.4;

Fig. 7C-E) has a straight crown that is pentagonal in cross-section. A medial ridge extends along the labial or lingual side of the crown whereas the opposing side is flattened. This specimen and other tooth fragments are covered by smooth enamel. ZIN $\mathrm{PH}$ 16/66 (MDD=2.9; LLD=1.7; Fig. 7A, B) is a small tooth with a short, unworn crown that is expanded beyond the root. It is likely a posterior replacement tooth, which had not yet erupted and lacked a fully formed root. The enamel is finely striated.

Comments. Nesov's (1995) identification of a titanosaurid or diplodocid sauropod with long and slender teeth covered by smooth enamel from Kansai was probably based on ZIN PH 18/66. No sauropod remains were recovered during largescale excavations at Kansai between 1964 and 1967 (Rozhdestvensky, 1977).

\subsection{Kyzylpilyal’ I (=Isfara II)}

Geographic position. Right bank of the Isfara river, $\mathrm{N}$ of Kyzylpilyal' village, southwestern Fergana Depression, Sughd Province, Tajikistan.

Stratigraphy. Yalovach Formation, lower Santonian (Nesov, 1997).

Material. Titanosauria indet.: teeth. this locality.

Comments. Nesov (1995) reported a sauropod with narrow pencil-like teeth from

\subsection{Changet IV}

Geographic position. Changet river near the mouth of the Bokai river, Fergana Depression, Jalal-Abad region, Kyrgyzstan.

Stratigraphy. Yalovach Formation, lower Santonian (Nesov, 1997).

Material. Sauropoda indet. 1995).

Comments. Unspecified remains of sauropods (Nesov et al., 1990; Nesov,

\subsection{Shakh-Shakh}

Geographic position. An exposure of Cretaceous deposits $70 \mathrm{~km} \mathrm{~N}$ of the Dzhusaly railway station, Lower Syr-Darya Uplift, northeastern Aral Sea region, Kyzylorda Province, Kazakhstan. al., 2016).

Stratigraphy. Bostobe Formation, Santonian - lower Campanian (Averianov et

Material. Titanosauria indet.: tooth.

Comments. Dyke and Malakhov (2004: fig. 4C) figured a pencil-like sauropod tooth from Shakh-Shakh with a crown that is slightly expanded beyond the root and covered by finely sculptured enamel. This tooth, with a median edge, is very similar to the tooth from the Kansai locality (Fig. 7C-E) and may belong to the same or a closely 
related taxon. The identification of sauropods from the nearby Baibishe I locality in the Bostobe Formation (Nesov, 1988, 1995) is based on small fragments of indeterminate pneumatized bone and cannot be confirmed.

\subsection{Kyrkkuduk I}

Geographic position. North of the Alymtau Range, 6-7 km S of the Kyrkkuduk well, southern Kazakhstan.

Stratigraphy. Syuksyuk Formation, Santonian (Nesov, 1997).

Material. Lithostrotia indet.: femur.

Comments. A sauropod from Kyrkkuduk was referred to Titanosauria closely related to taxa from the Upper Cretaceous of India (Anonymous, 1938). The identification was based on a femur similar to that referred to Antarctosaurus septentrionalis (Huene and Matley, 1933). This femur was referred to as cf. Antarctosaurus sp. or Antarctosaurus? jaxarticus sp. nov. [nomen nudum] (Riabinin, 1938). Efremov (1944) noted rare sauropod remains referable to Titanosauridae from this locality.

\subsection{Syuk-Syuk}

Geographic position. Cretaceous outcrops around Syuk-Syuk village, 10-12 km $\mathrm{N}$ of the Dzhylga railway station, southern Kazakhstan.

Stratigraphy. Syuksyuk Formation, Santonian (Nesov, 1997).

Material. Titanosauria indet.: tooth.

Comments. Nesov (1995) cited a long, narrow-crowned sauropod tooth from this locality.

\subsection{Shatyrtyube I}

Geographic position. A ravine $3 \mathrm{~km}$ SE of the isolated hill Shatyrtyube, vicinity of the Mullaly well, central Kyzylkum Desert, Navoi Viloyat, Uzbekistan.

Stratigraphy. Kynyr Formation, Santonian (Nesov, 1997).

Material. Titanosauria indet.: teeth.

Comments. Nesov (1995) mentioned sauropods with narrow teeth from this locality.

\subsection{Muinak}

Geographic position. Near the Muinak settlement on the former southern peninsula of the Aral Sea, Karakalpakistan, Uzbekistan.

Stratigraphy. Sands with Amphidonte asiatica, Upper Cretaceous, SantonianCampanian (?) (Nesov, 1997).

Material. Sauropoda indet.: bone fragments, including a rib fragment, collected by I.M. Abduazimova in 1990.

Comments. Nesov (1995) reported bones of sauropods from this locality. They are associated with teeth of marine sharks including Hispidaspis sp. cf. H. gigas (Nesov, unpublished notes).

\subsection{Kshi-Kalkan}

Geographic position. SW edge of the Kshi-Kalkan Mountains, on the right bank of the Ili River, Almaty Province, Kazakhstan. 
Stratigraphy. Unnamed Upper Cretaceous unit, Campanian-Maastrichtian (Averianov et al., 2012).

Material. Sauropoda indet.

Comments. Efremov (1944) mentioned sauropod bones possibly referable to Titanosauridae.

\subsection{Kara-Cheku (=Dzhurtas)}

Geographic position. $2 \mathrm{~km}$ SW of Kara-Chok village, on the right bank of the lli River, Almaty Province, Kazakhstan.

Stratigraphy. Unnamed Upper Cretaceous unit, Campanian-Maastrichtian (Averianov et al., 2012).

Material. Sauropoda indet.

Comments. Efremov (1944) noted numerous bones of Sauropoda (Titanosauridae) from this locality.

\section{Discussion}

According to Nesov (1995), all sauropods from Uzbekistan, beginning in the late Aptian (Karakul' locality), had narrow-crowned teeth with almost smooth enamel. Less well known sauropod teeth from the Upper Cretaceous of Tajikistan (Kansai) and Kazakhstan (Shakh-Shakh) are also narrow-crowned. This is in agreement with recent findings that all post-Cenomanian sauropods had narrow-crowned teeth (Barrett and Upchurch, 2005: fig. 4.3; Chure et al., 2010: fig. 5).

Nesov (1995) argued that sauropods dominated among the herbivorous dinosaurs during the Bathonian-Callovian of Central Asia and the Barremian-Aptian of Transbaikalia. A sauropod tooth from the marine Aptian Karakul' locality of Uzbekistan is likely a serendipitous discovery. In similar near-shore marine strata exposed at the Campanian Alymtau locality in southern Kazakhstan, not a single sauropod tooth was identified among thousands of vertebrate remains that include several ornithopod teeth (Averianov and Nesov, 1995). It seems likely that scarcity of sauropod fossils in the Upper Cretaceous of Central Asia reflects their actual rarity in the ecosystems from that interval. This also holds for the most productive Late Cretaceous vertebrate occurrence in the region, Dzharakuduk. Here sauropod teeth are much less common than teeth of hadrosauroids and theropods, and skeletal remains are rare (Sues et al., 2015).

Sauropod dominance lasted longer in East Asia. In the Ruyang Basin of Henan Province in China, the dinosaurian assemblage from the Cenomanian Mangchuan Formation includes gigantic sauropods, with three distinct taxa described to date (Lü et al., 2007; Lü et al., 2009a,b). All sauropod taxa from the Cretaceous of Eastern Asia are referable to Somphospondyli and can be attributed to two clades, Euhelopodidae and Titanosauria (Ksepka and Norell, 2006; Wilson and Upchurch, 2009; Ksepka and Norell, 2010; D'Emic, 2012; Mannion et al., 2013). Previous identifications of Brachiosauridae (Lim et al., 2001; You and Li, 2009) and Diplodocidae (Upchurch and Mannion, 2009) from the Cretaceous of Asia are based on specimens that are actually referable to one of the two somphospondylian groups (Barrett et al., 2002; Ksepka and Norell, 2010; Whitlock et al., 2011). Table 1 summarizes data for 14 somphospondylan taxa from the Cretaceous of East Asia that have been variously attributed to Titanosauria. However, the phylogenetic placements of the majority of these taxa vary considerably among published analyses (Table 2).

Among the Late Cretaceous somphospondylan sauropods from China, two taxa show similarities with the best-known sauropod from Central Asia, the titanosaur from the Bissekty Formation. Sues et al. (2015: fig. 7) already noted the similarity to 
Dongyangosaurus sinensis in the development of foramina in the postzygapophysealspinodiapophyseal fossa (posdf) on the anterior caudal vertebra. In addition to these features, there are also fossae on the prezygapophysis and anterior to the postzygapophysis, on the posterior surface of the transverse process (caudal rib) (Fig. 8). Two distinctive fossae on the posterior side of the transverse process of the first caudal vertebra were noted for Sonidosaurus saihangaobiensis although they are not visible in the published photograph (Xu et al., 2006: fig. 1(9)).

Another Chinese taxon similar to the Bissekty titanosaur is Baotianmansaurus henanensis. An anterior caudal (Zhang et al., 2009: fig. 4B-E) closely resembles USNM 538127 from Dzharakuduk (Sues et al., 2015: fig. 7), especially in its anteroposterior shortness (Fig. 8B, C), but the height of its centrum is proportionately greater. Unfortunately, the neural arch of the only known anterior caudal in Baotianmansaurus henanensis is poorly preserved and thus it is unclear if it had additional fossae like those present in Dongyangosaurus sinensis and the Bissekty titanosaur (Fig. 8). The dorsal vertebrae of Baotianmansaurus henanensis have large camerae separated by a thin median septum and the anterior condyles have camellate (somphospondylous) bone structure (Zhang et al., 2009: fig. 2D). The Bissekty titanosaur has similar adult dorsal vertebrae, with large camerae in the centrum separated by a thin septum and with a camellate condyle (Fig. 4C, D). The cervical vertebrae of the Bissekty titanosaur also have camellate condyles (Fig. 5C).

D'Emic (2012) referred both Baotianmansaurus and Dongyangosaurus to Euhelopodidae, specifically to the clade comprising Euhelopus zdanskyi and more derived euhelopodids. However, he provided lists of synapomorphies for Euhelopodidae and its subclades that mainly comprise features of the cervical vertebrae, none of which can currently be determined for the two Chinese taxa. Other potential synapomorphies are either unknown for Baotianmansaurus and Dongyangosaurus or absent (no ventral keels on the middle and posterior dorsal vertebrae and no tubercles on the dorsal margins of the prezygapophyses on the anterior caudal vertebrae). Thus reference of these taxa to Euhelopodidae cannot be supported by character evidence.

Mannion et al. (2013) referred Dongyangosaurus to Saltasauridae and recovered Baotianmansaurus as a saltasaurid or non-lithostrotian titanosaurian in different variations of their phylogenetic analysis. Unfortunately, these authors did not provide a list of synapomorphies for Saltasauridae and thus it is not clear which features link the two taxa to Saltasauridae. The anterior caudal vertebrae are amphicoelous in Baotianmansaurus and amphyplatian in Dongyangosaurus (Lu et al., 2008; Zhang et al., 2009). The absence of procoelous caudal vertebrae in the latter taxa suggests that they are non-lithostrotian titanosaurs. The anterior caudal of the Bissekty titanosaur is also amphiplatyan (Sues et al., 2015). The known middle caudals are also not procoelous (Sues et al., 2015). This and the apparent lack of osteoderms suggest that the Bissekty sauropod is a non-lithostrotian titanosaur. The extensive pneumatization of the neural arch on the anterior caudal vertebra, revealed by additional fossae, hints at a possible relationship between the Bissekty titanosaur and Dongyangosaurus.

Baotianmansaurus is similar to Dongyangosaurus in the presence of three laminae supporting the parapophysis on the dorsal vertebrae and resembles the Bissekty titanosaur in the unusually short anterior caudal centrum. Possibly these three taxa represent an as yet formally unrecognized endemic clade of Asian titanosaurs.

Borealosaurus wimani was referred to Saltasauridae (?Opisthocoelicaudiinae) based on the opisthocoelous condition of the middle caudal vertebra (You et al., 2004). The referred tooth is likely an upper tooth with two lateral wear facets (V-shaped pattern) and with smooth enamel (contra You et al., 2004). However, opisthocoely occurs in different regions of the tail and to different degrees in Borealosaurus and Opisthocoelicaudia, and opisthocoelous middle caudals are more widely distributed 
among Titanosauriformes (Azuma and Shibata, 2010; D'Emic et al., 2013). Based on the absence of procoelous middle caudal vertebrae, Borealosaurus is probably a nonlithostrotian titanosaur.

Daxiatitan binglingi, with non-bifid neural spines on the cervical vertebrae and strongly procoelous anterior and middle caudal vertebrae (You et al., 2008; Mannion et al., 2013), is likely a lithostrotian titanosaur rather than a euhelopodid (D'Emic, 2012). Unlike in saltasaurids, its femur has dorsolaterally rather than dorsomedially beveled distal condyles (Wilson, 2005a; You et al., 2008). Furthermore, the acromion process of the scapula is well-developed in Daxiatitan and a number of basal titanosauriforms but is reduced in derived titanosaurs (Mannion and Otero, 2012). These features support interpretation of Daxiatitan as a non-saltasaurid lithostrotian.

Jiangshanosaurus xinwaensis was originally described as a "titanosaurid" (Tang et al., 2001). D'Emic (2012) and Mannion et al. (2013) considered it a saltasaurid, which is of interest in view of its Albian age. The scapulocoracoid of Jiangshanosaurus shares certain similarities with that of Alamosaurus sanjuanensis: the acromion process of scapula is reduced; the scapulocoracoid suture is flush with the dorsal margin, without an embayment at the suture; and the anteroventral margin of the coracoid is rectangular (rather than round as in Opisthocoelicaudia; Borsuk-Białynicka, 1977: fig. 6). The coracoid foramen is positioned close to or on the scapulocoracoid suture in Neuquensaurus australis, Rapetosaurus krausei, and Saltasaurus loricatus, but occupies a more central position on the coracoid in Jiangshanosaurus, Opisthocoelicaudia, and Vahiny depereti (Curry Rogers, 2009). Tang et al. (2001: p. 278) described the articulation between the centra as "distinctly procoelous" for the anterior caudal vertebrae and "mildly procoelous" for the middle caudals. However, these contacts are more accurately described as slightly procoelous on the first caudal and amphiplatyan on the middle caudals (Tang et al., 2001: pl. 2, figs. 1-4, 6, 8-11). The neural arch on the caudal vertebrae is positioned on the anterior half of the centrum according to Tang et al. (2001: p. 278), but it actually has a more central position compared to other titanosauriforms. Poropat et al. (2015) noted the similarity between Diamantinasaurus matildae, Opisthocoelicaudia, Malawisaurus dixeyi, and Jiangshanosaurus in the presence of paired (dorsally bifurcated) posterior centroparapophyseal laminae (pcpl) on the middle and posterior dorsal vertebrae. The mosaic combination of a relatively derived pelvic girdle with a plesiomorphic pattern of caudal vertebrae in Jiangshanosaurus renders its phylogenetic placement problematical. Here it is considered a non-lithostrotian titanosaur based on the absence of pronounced procoely on the anterior and middle caudal vertebrae.

Qingxiusaurus youjiangensis was based on isolated humeri, sternal plates, and the neural spine of an anterior caudal vertebra (Mo et al., 2008). The simple, paddleshaped neural spine of the anterior caudal resembles that of an isolated sauropod vertebra from the Cretaceous of the neighboring Guizhou Province (Young, 1948), which may belong to the same or a closely related taxon. The humerus of Qingxiusaurus has a well-developed posterolateral bulge. This feature is considered a synapomorphy for Saltasauridae (D'Emic, 2012). The posterolateral bulge is also present in the saltasaurids Opisthocoelicaudia (Borsuk-Białynicka, 1977: fig. 7C, D), Alamosaurus, and Saltasaurus, in the non-lithostrotian titanosaur Dreadnoughtus (Lacovara et al., 2014), and in Jainosaurus septentrionalis, a titanosaurian of uncertain affinities (Wilson et al., 2011). Wilson et al. (2009) noted a similarity between Qingxiusaurus and Jainosaurus in the expanded and anteriorly exposed radial condyle of the humerus whereas the ulnar condyle is not. Qingxiusaurus is here considered a saltasaurid.

Sonidosaurus saihangaobiensis has a distinctly opisthocoelous first caudal vertebra (Xu et al., 2006: fig. 1(8)). It resembles Opisthocoelicaudia, Saltasaurus, 
Neuquensaurus, and the Bor Guvé titanosaur in having a posterior centrodiapophyseal lamina (pcdl) on the dorsal vertebrae (Ksepka and Norell, 2010). Sonidosaurus has several derived features in the structure of the pelvis, including the pneumatization of the ilium (Xu et al., 2006; Mannion and Calvo, 2011; Poropat et al., 2015). Sonidosaurus is here considered a non-saltasaurid lithostrotian with possible saltasaurid affinities.

The phylogenetic position of the recently described Yongjinglong datangi is difficult to assess due to its peculiar combination of a Euhelopus-like vertebral column and teeth and an Opisthocoelicaudia-like pectoral girdle and forelimb (Li et al., 2014; Saegusa and Ikeda, 2014). Saegusa and Ikeda (2014) raised a possibility that Yongjinglong represents a mixture of skeletal elements of more than one individual or taxon. Here we accept a conservative assessment of Yongjinglong as a nonlithostrotian titanosaur.

Xianshanosaurus shijiagouensis was originally placed as Neosauropoda incertae sedis (Lü et al., 2009b). It is not clear whether the isolated tooth with a spatulate crown and median ridge (Lü et al., 2009b: fig. 5E) belongs with the caudal vertebrae and limb bones. The Mangchuan Formation has yielded skeletal remains representing at least three different sauropod taxa (Lü et al., 2007; Lü et al., 2009a; Lü et al., 2009b). The anterior caudal centra of Xianshanosaurus are distinctly procoelous (Lü et al., 2009b: fig. 7B). This taxon differs from most other Titanosauriformes in having proximally closed anterior hemal arches (Poropat et al., 2015). We follow Wedel and Taylor (2013) in considering Xianshanosaurus a non-saltasaurid lithostrotian.

The stratigraphic distribution of Cretaceous sauropods in Central and East Asia is summarized in Fig. 9. At least for the second half of the Early Cretaceous, nonlithostrotian titanosaurs co-existed with the non-titanosaurian somphospondylans, mostly euhelopodids. The stratigraphically youngest known non-titanosaurian somphospondylan in Asia is Ruyangosaurus giganteus from the Cenomanian Mangchuan Formation of Henan (China). In Central Asia, skeletal remains of sauropods are known mainly from the Turonian Bissekty Formation. The Bissekty titanosaur is likely a non-lithostrotian titanosaur. Isolated narrow-crowned teeth from other Cretaceous strata in Central Asia are tentatively referred to this evolutionary grade although at least some of them may belong to more derived lithostrotian taxa. Baotianmansaurus, Dongyangosaurus, and the Bissekty titanosaur possibly represent an endemic clade of non-lithostrotian titanosaurs that is particularly characterized by extensive pneumatization of the neural arches on the anterior caudal vertebrae.

The stratigraphically oldest known non-saltasaurid lithostrotian in Asia is Daxiatitan binglingi from the Aptian Hekou Group of Gansu (China) (You et al., 2008). Non-saltasaurid lithostrotians coexisted with the non-lithostrotian titanosaurs during the Aptian-Santonian interval. In Central Asia, the only report of a non-saltasaurid lithostrotian is from the Syuksyuk Formation of southern Kazakhstan, from which a femur similar to that of Indian Maastrichtian titanosaurs was reported (Riabinin, 1938). Sauropod teeth with pentagonal cross-sections from the Santonian Yalovach and Bostobe formations of Tajikistan and western Kazakhstan, respectively, are quite different from the cylindrical teeth from the Cenomanian-Coniacian strata of the Kyzylkum Desert. This change in dental morphology may be related to the replacement of non-lithostrotian titanosaurs by non-saltasaurid lithostrotians in the region.

There are as yet no definitive records of saltasaurids from the Upper Cretaceous of Central Asia. Post-Santonian continental vertebrate assemblages from this region are still poorly known. This is in part due to the fact that a marine transgression started in the Campanian and inundated most of the region until the end of the Cretaceous. The only region that was not affected by this transgression is eastern Kazakhstan (Averianov et al., 2012). However, the Campanian-Maastrichtian dinosaurian faunas of 
the latter region are barely known, although abundant sauropod remains have been reported from there (see localities 2.23 and 2.24).

Definitive records of saltasaurids in Asia are known only from the CampanianMaastrichtian Barun Goyot and Nemegt formations of the Gobi Desert in Mongolia (Fig. 9). The saltasaurid Qingxiusaurus from the Upper Cretaceous of Guangxi (China) is possibly also Campanian-Maastrichtian in age. Figure 9 shows the gradual evolution of sauropods in Asia with stepwise replacement of more basal taxa by more derived forms and the co-existence of the two grades in various ecosystems.

\section{Conclusions}

To date 24 localities with Cretaceous vertebrate fossils in the republics of Central Asia (Kazakhstan, Kyrgyzstan, Tajikistan, and Uzbekistan) have yielded remains of sauropod dinosaurs. Sauropods are among the least common non-avian dinosaurs at all localities and are usually represented only by a few isolated teeth. Only narrowcrowned sauropod teeth are known from the Cretaceous of Central Asia. The oldest record of such teeth is from the Aptian Sultanbobo Formation of Uzbekistan. Exposures of the Turonian Bissekty Formation at Dzharakuduk (Uzbekistan) have yielded many isolated teeth and some skeletal remains referable to a probably non-lithostrotian titanosaur. Similar narrow-crowned teeth from Cenomanian- to Coniacian-age strata in the Kyzylkum Desert, Uzbekistan, possibly represent a closely related taxon. Another taxon, with teeth that are pentagonal in cross-section, is known from the Santonian Yalovach and Bostobe formations of Tajikistan and western Kazakhstan, respectively. A femur reported from the Santonian Syuksyuk Formation of southern Kazakhstan possibly represented a lithostrotian titanosaur. Changes in sauropod tooth structure at the Coniacian-Santonian boundary in the region possibly suggest replacement of nonlithostrotian titanosaurs by lithostrotians. The titanosaur from the Bissekty Formation resembles Dongyangosaurus sinensis from the Cenomanian-Turonian of Zhejiang (China) in the extensive pneumatization of the neural arch on the anterior caudal vertebrae with several fossae. Furthermore, it resembles Baotianmansaurus henanensis from the Cenomanian of Henan (China) in the possession of very short anterior caudal centra. These three taxa may represent an as yet formally unrecognized endemic clade of Asian non-lithostrotian titanosaurs.

\section{Acknowledgments}

Fieldwork in Uzbekistan was facilitated by and conducted in cooperation with the Zoological Institute of the National Academy of Sciences of Uzbekistan, particularly D.A. Azimov and Y.A. Chikin. For their efforts in the field, scientific expertise, and camaraderie, we thank A.V. Abramov, J.D. Archibald, G.O. Cherepanov, I.G. Danilov, S. Dominguez, N. Morris, C.M. Redman, A.S. Resvyi, C. Skrabec, P.P. Skutschas, E.V. Syromyatnikova, and D.J. Ward. The editor and two anonymous reviewers provided helpful comments on a draft of the manuscript. The field work in 1997-2006 was funded by the National Science Foundation (EAR-9804771 and EAR-0207004 to J.D. Archibald and H.-D. Sues), the National Geographic Society (5901-97 and 6281-98 to J.D. Archibald and H.-D. Sues), and the Navoi Mining and Metallurgy Combinat. The laboratory research by AA is supported by the Russian Scientific Fund (14-14-00015).

\section{References}

Anonymous, 1938. [Dinosaur remains in Kazakhstan]. Vestnik Znaniya, 74. 
Archibald, J.D., Sues, H.-D., Averianov, A.O., King, C., Ward, D.J., Tsaruk, O.I., Danilov, I.G., Rezvyi, A.S., Veretennikov, B.G. and Khodjaev, A. 1998. Précis of the Cretaceous paleontology, biostratigraphy and sedimentology at Dzharakuduk (Turonian?-Santonian), Kyzylkum Desert, Uzbekistan. New Mexico Museum of Natural History and Science Bulletin 14, 21-28.

Averianov, A.O., 2006. On an ornithomimid dinosaur (Saurischia, Ornithomimosauria) from the Cenomanian of Fergana. Paleontological Journal 40, 323-327.

Averianov, A., 2014. Review of taxonomy, geographic distribution, and paleoenvironments of Azhdarchidae (Pterosauria). ZooKeys 432, 1-107.

Averianov, A.O., Danilov, I.G., Skutschas, P.P., Kuzmin, I.T., Sues, H.-D., Dyke, G.J., 2016. The Late Cretaceous vertebrate assemblages of western Kazakhstan. New Mexico Museum of Natural History and Science Bulletin 71, 5-17.

Averianov, A.O., Nesov, L.A., 1995. A new Cretaceous mammal from the Campanian of Kazakhstan. Neues Jahrbuch für Geologie und Paläontologie Monatshefte 1995, 65-74.

Averianov, A.O., Sues, H.-D., 2007. A new troodontid (Dinosauria: Theropoda) from the Cenomanian of Uzbekistan, with a review of troodontid records from the territories of the former Soviet Union. Journal of Vertebrate Paleontology 27, 8798.

Averianov, A., Sues, H.-D., 2016. Sauropod teeth from the Upper Cretaceous Bissekty Formation of Uzbekistan. Historical Biology

Averianov, A.O., Sues, H.-D., Tleuberdina, P.A., 2012. The forgotten dinosaurs of Zhetysu (eastern Kazakhstan; Late Cretaceous). Proceedings of the Zoological Institute of the Russian Academy of Sciences 316, 139-147.

Azuma, Y., Shibata, M., 2010. Fukuititan nipponensis, a new titanosauriform sauropod from the Early Cretaceous Tetori Group of Fukui Prefecture, Japan. Acta Geologica Sinica 84, 454-462.

Barrett, P.M., Hasegawa, Y., Manabe, M., Isaji, S., Matsuoka, H., 2002. Sauropod dinosaurs from the Lower Cretaceous of eastern Asia: taxonomic and biogeographical implications. Palaeontology 45, 1197-1217.

Barrett, P.M., Upchurch, P., 2005. Sauropodomorph diversity through time, in: Curry Rogers, K.A., Wilson, J.A. (Eds.), The Sauropods: Evolution and Paleobiology. University of California Press, Berkeley, pp. 125-156.

Borsuk-Białynicka, M., 1977. A new camarasaurid sauropod Opisthocoelicaudia skarzynskii, gen. n., sp. n. from the Upper Cretaceous of Mongolia.

Palaeontologia Polonica 37, 1-64.

Chure, D.J., Britt, B.B., Whitlock, J.A., Wilson, J.A., 2010. First complete sauropod dinosaur skull from the Cretaceous of the Americas and the evolution of sauropod dentition. Naturwissenschaften 97, 379-391.

Curry Rogers, K.A., 2005. Titanosauria: a phylogenetic overview, in: Curry Rogers, K.A., Wilson, J.A. (Eds.), The Sauropods: Evolution and Paleobiology. University of California Press, Berkeley, pp. 50-193.

Curry Rogers, K.A., 2009. The postcranial osteology of Rapetosaurus krausei (Sauropoda: Titanosauria) from the Late Cretaceous of Madagascar. Journal of Vertebrate Paleontology 29, 1046-1086.

D'Emic, M.D., 2012. The early evolution of titanosauriform sauropod dinosaurs. Zoological Journal of the Linnean Society 166, 624-671.

D'Emic, M.D., Mannion, P.D., Upchurch, P., Benson, R.B.J., Pang, Q., Cheng, Z., 2013. Osteology of Huabeisaurus allocotus (Sauropoda: Titanosauriformes) from the Upper Cretaceous of China. PLoS ONE 8, e69375. 
Dyke, G.J., Malakhov, D.V., 2004. Abundance and taphonomy of dinosaur teeth and other vertebrate remains from the Bostobynskaya Formation, north-east Aral Sea region, Republic of Kazakhstan. Cretaceous Research 25, 669-674.

Efremov, I.A., 1944. [Dinosaur horizon of Middle Asia and some questions of stratigraphy]. Izvestiya Akademii Nauk SSSR, Seriya Geologicheskaya, 40-58.

Huene, F. von, Matley, C.A., 1933. Cretaceous Saurischia and Ornithischia of the central provinces of India. Palaeontologia Indica, New Series, 21(1), 1-74.

Janensch, W., 1950. Die Wirbelsäule von Brachiosaurus brancai. Palaeontographica, Suppl. 7, 1(3), 27-93.

Ksepka, D.T., Norell, M.A., 2006. Erketu ellisoni, a long-necked sauropod from Bor Guvé (Dornogov Aimag, Mongolia). American Museum Novitates 3508, 1-16.

Ksepka, D.T., Norell, M.A., 2010. The illusory evidence for Asian Brachiosauridae: new material of Erketu ellisoni and a phylogenetic reappraisal of basal Titanosauriformes. American Museum Novitates 3700, 1-27.

Kurzanov, S.M., Bannikov, A.F., 1983. [A new sauropod from the Upper Cretaceous of Mongolia]. Paleontologicheskii Zhurnal 1983(2), 90-96.

Lacovara, K.J., Lamanna, M.C., Ibiricu, L.M., Poole, J.C., Schroeter, E.R., Ullmann, P.V., Voegele, K.K., Boles, Z.M., Carter, A.M., Fowler, E.K., Egerton, V.M., Moyer, A.E., Coughenour, C.L., Schein, J.P., Harris, J.D., Martínez, R.D., Novas, F.E., 2014. A gigantic, exceptionally complete titanosaurian sauropod dinosaur from southern Patagonia, Argentina. Scientific Reports 4, 6196.

Li, L.-G., Li, D.-Q., You, H.-L., Dodson, P., 2014. A new titanosaurian sauropod from the Hekou Group (Lower Cretaceous) of the Lanzhou-Minhe Basin, Gansu Province, China. PLoS ONE 9, e85979.

Lim, J.-D., Martin, L.D., Baek, K.-S., 2001. The first discovery of a brachiosaurid from the Asian continent. Naturwissenschaften 88, 82-84.

Lü, J., Azuma, Y., Chen, R., Zheng, W., Jin, X., 2008. A new titanosauriform sauropod from the early Late Cretaceous of Dongyang, Zhejiang Province. Acta Geologica Sinica 82, 225-235.

Lü, J.-C., Xu, L., Jia, S.-H., Zhang, X.-L., Zhang, J.-M., Yang, L.-L., You, H.-L., Ji, Q., 2009a. A new gigantic sauropod dinosaur from the Cretaceous of Ruyang, Henan, China. Geological Bulletin of China 28, 1-10.

Lü, J., Xu, L., Jiang, X., Jia, S., Li, M., Yuan, C., Zhang, X., Ji, Q., 2009b. A preliminary report on the new dinosaurian fauna from the Cretaceous of the Ruyang Basin, Henan Province of central China. Journal of the Paleontological Society of Korea 25, 43-56.

Lü, J., Xu, L., Zhang, X., Hu, W., Wu, Y., Jia, S., Ji, Q., 2007. A new gigantic sauropod dinosaur with the deepest known body cavity from the Cretaceous of Asia. Acta Geologica Sinica 81, 167-176.

Mannion, P.D., 2011. A reassessment of Mongolosaurus haplodon Gilmore, 1933, a titanosaurian sauropod dinosaur from the Early Cretaceous of Inner Mongolia, People's Republic of China. Journal of Systematic Palaeontology 9, 355-378.

Mannion, P.D., Calvo, J.O., 2011. Anatomy of the basal titanosaur (Dinosauria, Sauropoda) Andesaurus delgadoi from the mid-Cretaceous (Albian-early Cenomanian) Río Limay Formation, Neuquén Province, Argentina: implications for titanosaur systematics. Zoological Journal of the Linnean Society 163, 155181.

Mannion, P.D., Otero, A., 2012. A reappraisal of the Late Cretaceous Argentinean sauropod dinosaur Argyrosaurus superbus, with a description of a new titanosaur genus. Journal of Vertebrate Paleontology 32, 614-638.

Mannion, P.D., Upchurch, P., Barnes, R.N., Mateus, O., 2013. Osteology of the Late Jurassic Portuguese sauropod dinosaur Lusotitan atalaiensis (Macronaria) and 
the evolutionary history of basal titanosauriforms. Zoological Journal of the Linnean Society 168, 98-206.

Mannion, P.D., Upchurch, P., Carrano, M.T., Barrett, P.M., 2011. Testing the effect of the rock record on diversity: a multidisciplinary approach to elucidating the generic richness of sauropodomorph dinosaurs through time. Biological Reviews 86, 157-181.

Maryańska, T., 2000. Sauropods from Mongolia and the former Soviet Union, in:

Benton, M.J., Shishkin, M.A., Unwin, D.M., Kurochkin, E.N. (Eds.), The Age of Dinosaurs in Russia and Mongolia. Cambridge University Press, Cambridge, pp. 456-461.

Mclntosh, J.S., 1990. Sauropoda, in: Weishampel, D.B., Dodson, P., Osmólska, H. (Eds.), The Dinosauria. University of California Press, Berkeley, pp. 345-401.

Mertiniene, R.A., Nesov, L.A., Nazarkin, M.V., 1994. Cretaceous sharks of the genus Paraisurus in Uzbekistan and Lithuania. Geologija 17, 139-143.

Mo, J.-Y., Huang, C.-L., Zhao, Z.-R., Wang, W., Xu, X., 2008. A new titanosaur

(Dinosauria: Sauropoda) from the Late Cretaceous of Guangxi, China. Vertebrata PalAsiatica 46, 147-165.

Nesov, L.A., 1988. [Assemblages of late Mesozoic and Paleocene vertebrates of Middle Asia], in: Bogdanova, T.N., Oshurkova, M.V. (Eds.), [Formation and Evolution of the Continental Biotas]. Izdatelstvo Nauka, Leningrad, pp. 93-101.

Nesov, L.A., 1995. [Dinosaurs of Northern Eurasia: New Data about Assemblages, Ecology and Paleobiogeography]. Izdatelstvo Sankt-Peterburgskogo Universiteta, Saint Petersburg.

Nesov, L.A., 1997. [Cretaceous Nonmarine Vertebrates of Northern Eurasia] (Posthumous edition by L.B. Golovneva and A.O. Averianov). Izdatel'stvo SanktPeterburgskogo Universiteta, Saint Petersburg.

Nesov, L.A., Fedorov, P.V., Udovichenko, N.I., 1990. [Vertebrates of the Jurassic, Cretaceous and Paleogene of north-eastern Fergana and their significance for the clarification of the age of deposits and past environment. II. Late Cretaceous and Paleogene. Description of new vertebrates from the Jurassic]. Vestnik Leningradskogo Universiteta, Seriya 7, Geologiya, Geografiya 1, 8-18.

Nowinski, A., 1971. Nemegtosaurus mongoliensis n. gen., n. sp. (Sauropoda) from the uppermost Cretaceous of Mongolia. Palaeontologia Polonica 25, 57-81.

Poropat, S.F., Upchurch, P., Mannion, P.D., Hocknull, S.A., Kear, B.P., Sloan, T., Sinapius, G.H.K., Elliott, D.K., 2015. Revision of the sauropod dinosaur Diamantinasaurus matildae Hocknull et al. 2009 from the mid-Cretaceous of Australia: implications for Gondwanan titanosauriform dispersal. Gondwana Research 27, 995-1033.

Riabinin, A.N., 1938. [Some results of the studies of the Upper Cretaceous dinosaurian fauna from the vicinity of the station Sary-Agach, South Kazakhstan]. Problemy Paleontologii 4, 125-135.

Rozhdestvensky, A.K., 1964. [New data on the localities of dinosaurs on the territory of Kazakhstan and Middle Asia]. Nauchnye Trudy Tashkentskogo

Gosudarstvennogo Universiteta Imeni V.I. Lenina, Seriya Geologiya 234, 227241.

Rozhdestvensky, A.K., 1973. [Study of Cretaceous reptiles in Russia].

Paleontologicheskii Zhurnal 1973(2), 90-99.

Rozhdestvensky, A.K., 1977. [Kansai locality of Cretaceous vertebrates in Fergana]. Ezhegodnik Vsesoyuznogo Paleontologicheskogo Obshchestva 20, 235-247.

Rozhdestvensky, A.K., Khozatsky, L.I., 1967. [Late Mesozoic terrestrial vertebrates of Asiatic part of the USSR], in: Martinson, G.G. (Ed.), [Stratigraphy and 
Paleontology of Mesozoic and Paleogene-Neogene Continental Deposits of Asiatic Part of the USSR]. Nauka, Leningrad, pp. 82-92.

Saegusa, H., Ikeda, T., 2014. A new titanosauriform sauropod (Dinosauria: Saurischia) from the Lower Cretaceous of Hyogo, Japan. Zootaxa 3848, 1-66.

Sosedko, A.F., 1937. [Cemetery of vertebrates in the center of Kyzyl-Kum Desert]. Sotsialisticheskaya Nauka i Tekhnika, 106-111.

Sues, H.-D., Averianov, A., Ridgely, R.C., Witmer, L.M., 2015. Titanosauria (Dinosauria: Sauropoda) from the Upper Cretaceous (Turonian) Bissekty Formation of Uzbekistan. Journal of Vertebrate Paleontology 35, e889145.

Tang, F., Kang, X.-M., Jin, X.-S., Wei, F., Wu, W.-T., 2001. A new sauropod dinosaur of Cretaceous from Jiangshan, Zhejiang Province. Vertebrata PalAsiatica 39, $272-$ 281.

Upchurch, P., 1998. The phylogenetic relationships of sauropod dinosaurs. Zoological Journal of the Linnean Society 124, 43-103.

Upchurch, P., Barrett, P.M., Dodson, P., 2004. Sauropoda, in: Weishampel, D.B., Dodson, P., Osmólska, H. (Eds.), The Dinosauria. Second Edition. University of California Press, Berkeley, pp. 259-322.

Upchurch, P., Mannion, P.D., 2009. The first diplodocid from Asia and its implications for the evolutionary history of sauropod dinosaurs. Palaeontology 52, 1195-1207.

Wedel, M.J., 2003. The evolution of vertebral pneumaticy in sauropod dinosaurs. Journal of Vertebrate Paleontology 23, 344-357.

Wedel, M.J., Taylor, M.P., 2013. Caudal pneumaticity and pneumatic hiatuses in the sauropod dinosaurs Giraffatitan and Apatosaurus. PLoS ONE 8, e78213.

Whitlock, J.A., D'Emic, M.D., Wilson, J.A., 2011. Cretaceous diplodocids in Asia? Reevaluating the phylogenetic affinities of a fragmentary specimen. Palaeontology 54, 351-364.

Wilson, J.A., 2005a. Overview of sauropod phylogeny and evolution, in: Curry Rogers, K.A., Wilson, J.A. (Eds.), The Sauropods: Evolution and Paleobiology. University of California Press, Berkeley, pp. 15-49.

Wilson, J.A., 2005b. Redescription of the Mongolian sauropod Nemegtosaurus mongoliensis Nowinski (Dinosauria: Saurischia) and comments on Late Cretaceous sauropod diversity. Journal of Systematic Palaeontology 3, 283-318.

Wilson, J.A., Barrett, P.M., Carrano, M.T., 2011. An associated partial skeleton of Jainosaurus cf. septentrionalis (Dinosauria: Sauropoda) from the Late Cretaceous of Chhota Simla, Central India. Palaeontology 54, 981-998.

Wilson, J.A., D'Emic, M.D., Curry Rogers, K.A., Mohabey, D.M., Sen, S., 2009. Reassessment of sauropod dinosaur Jainosaurus (="Antarctosaurus") septentrionalis from the Upper Cretaceous of India. Contributions from the Museum of Paleontology, University of Michigan 32, 17-40.

Wilson, J.A., Upchurch, P., 2009. Redescription and reassessment of the phylogenetic affinities of Euhelopus zdanskyi (Dinosauria: Sauropoda) from the Early Cretaceous of China. Journal of Systematic Palaeontology 7, 199-239.

Xu, X., Zhang, X., Tan, Q., Zhao, X., Tan, L., 2006. A new titanosaurian sauropod from Late Cretaceous of Nei Mongol, China. Acta Geologica Sinica 80, 20-26.

You, H., Ji, Q., Lamanna, M.C., Li, J., Li, Y., 2004. A titanosaurian sauropod dinosaur with opisthocoelous caudal vertebrae from the early Late Cretaceous of Liaoning Province, China. Acta Geologica Sinica 78, 907-911.

You, H.-L., Li, D.-Q., 2009. The first well-preserved Early Cretaceous brachiosaurid dinosaur in Asia. Proceedings of the Royal Society B 276, 4077-4082.

You, H.-L., Li, D.-Q., Zhou, L.-Q., Ji, Q., 2008. Daxiatitan binglingi: a giant sauropod dinosaur from the Early Cretaceous of China. Gansu Geology 17, 1-10. 
Young, C.C., 1948. Notes on the occurrence of sauropod remains from N. Kweichow, China. Science Record 2, 200-206.

Zhang, X., Lü, J., Xu, L., Li, J., Yang, L., Hu, W., Jia, S., Ji, Q., Zhang, C., 2009. A new sauropod dinosaur from the Late Cretaceous Gaogou Formation of Nanyang, Henan Province. Acta Geologica Sinica 83, 212-221.

\section{Figure captions}

Fig. 1. Map of Central Asia (Kazakhstan, Kyrgyzstan, Tajikistan, and Uzbekistan) showing sauropod localities discussed in the text. Localities: 1, Karakul'; 2, Khodzhakul; 3, Sheikhdzheili; 4, Khodzhakul'sai; 5, Chelpyk; 6, Itemir; 7, Karachadalysai; 8, Gul'cha; 9, Suzak; 10, Kulkuduk; 11, Dzharakuduk; 12, Zenge Kurgan 3; 13, Dzhara; 14, Tyulkili; 15, Kansai; 16, Kyzylpilyal' I; 17, Changet IV; 18, Shakh-Shakh; 19, Kyrkkuduk I; 20, Syuk-Syuk; 21, Shatyrtyube I; 22, Muinak; 23, Kshi-Kalkan; 24, Kara-Cheku. [Intended for page width]

Fig. 2. Isolated sauropod teeth from the localities Karakul' (A, B), Khodzhakul (C-I), and Sheikhdzheili (J-R). A, B, ZIN PH 2431/16, lower tooth, in mesial or distal (A) and labial (B) views; C-E, ZIN PH 2429/16, upper tooth, in labial (C), mesial or distal (D), and lingual (E) views; F, G, ZIN PH 2428/16, lower tooth, in labial (F) and mesial or distal (G) views; H, I, ZIN PH 2430/16, upper tooth, in mesial or distal $(H)$ and lingual (I) views; J-L, ZIN PH 2424/16, upper tooth, in lingual (J), mesial or distal (K), and labial (L) views; ZIN PH 2425/16, upper tooth, in lingual (M), mesial or distal (N), and labial (O) views; ZIN PH 2426/16, lower tooth, in lingual (P), mesial or distal $(Q)$, and labial $(R)$ views. Abbreviations: A1, A2, apical wear facets 1 and 2; L1-L3, lateral wear facets 1 to 3. Scale bars each equal $1 \mathrm{~mm}$. [Intended for page width]

Fig. 3. Isolated sauropod teeth from the localities Khodzhakul'sai (A-C), Chelpyk (D, E), Itemir (F-H), and Zenge Kurgan 3 (I-N). A-C, ZIN PH 2432/16, lower tooth, in lingual (A), mesial or distal (B), and labial (C) views; D, E, ZIN PH 2433/16, unworn replacement tooth, in labial or lingual (D) and mesial or distal (E) views; F-H, ZIN PH 2434/16, upper tooth, in lingual $(F)$, mesial or distal $(G)$, and labial $(H)$ views; I-K, ZIN PH 2438/16, upper tooth, in lingual (I), mesial or distal (J), and labial (K) views; L-N, ZIN PH 2437/16, upper tooth, in lingual (L), mesial or distal (M), and labial $(\mathrm{N})$ views. Abbreviations: $A 1$, A2, apical wear facets 1 and 2; L1, lateral wear facet 1 . Scale bars each equal $1 \mathrm{~mm}$. [Intended for page width]

Fig. 4. ZIN PH 2439/16, incomplete centrum of a dorsal vertebra of Titanosauria indet. from the Bissekty Formation (Turonian) of Dzharakuduk, Uzbekistan. A, anterior view; $B$, posterior view; $C$, ventral view; $D$, dorsal view. Abbreviations: ms, median septum; pf, pneumatic foramen; pl, pleurocoel. Scale bar equals $5 \mathrm{~cm}$. [Intended for column width]

Fig. 5. IZANUZ 335, incomplete centrum of a cervical vertebra of Titanosauria indet. from the Bissekty Formation (Turonian) of Dzharakuduk, Uzbekistan. A, dorsal view; B, lateral view; $C$, ventral view; $D$, diagrammatic reconstruction of the cervical vertebra showing position of the preserved fragment. Scale bars each equal $10 \mathrm{~cm}$. [Intended for column width]

Fig. 6. ZIN PH 2/111, centrum of a posterior caudal vertebra of Titanosauriformes indet. from the Zhirkindek Formation (Turonian) of Tyulkili, Kazakhstan. A, anterior view; B, 
dorsal view; C, lateral view; D, posterior view; E, ventral view. Scale bar equals $3 \mathrm{~cm}$. [Intended for column width]

Fig. 7. Isolated sauropod teeth from the Yalovach Formation (Santonian) of Kansai, Tajikistan. A, B, ZIN PH 16/66, unworn replacement tooth, in labial or lingual $(A)$ and mesial or distal (B) views; A-C, ZIN PH 18/66, in labial or lingual (C, E) and mesial or distal (D) views. Scale bars each equal $1 \mathrm{~mm}$. [Intended for column width]

Fig. 8. Anterior caudal vertebrae of Dongyangosaurus sinensis (A), the Bissekty titanosaur (B), and Baotianmansaurus henanensis (C), in lateral view. A, first and second caudals, modified from Lü et al. (2008: pl. 2, fig. B); B, first or second caudal, reversed and modified from Sues et al. (2015: fig. 7C); C, first caudal, modified from Zhang et al. (2009: fig. 4D). Abbreviations: poz, postzygapophysis; posdf, postzygapophyseal-spinodiapophyseal fossa; spdl, spinodiapophyseal lamina; trp, transverse process. Arrows indicate additional small fossae. Scale bars each equal 10 $\mathrm{cm}$. [intended for page width]

Fig. 9. Stratigraphic distribution of sauropod dinosaurs in selected Cretaceous sections of Central and East Asia. Abbreviations: BG, Barun Goyot; Bi, Bissekty; Cen, Cenomanian; Con, Coniacian; LBS, Lower Bayn Shire; Tur, Turonian; S, Santonian; UBS, Upper Bayn Shire. [Intended for page width] 


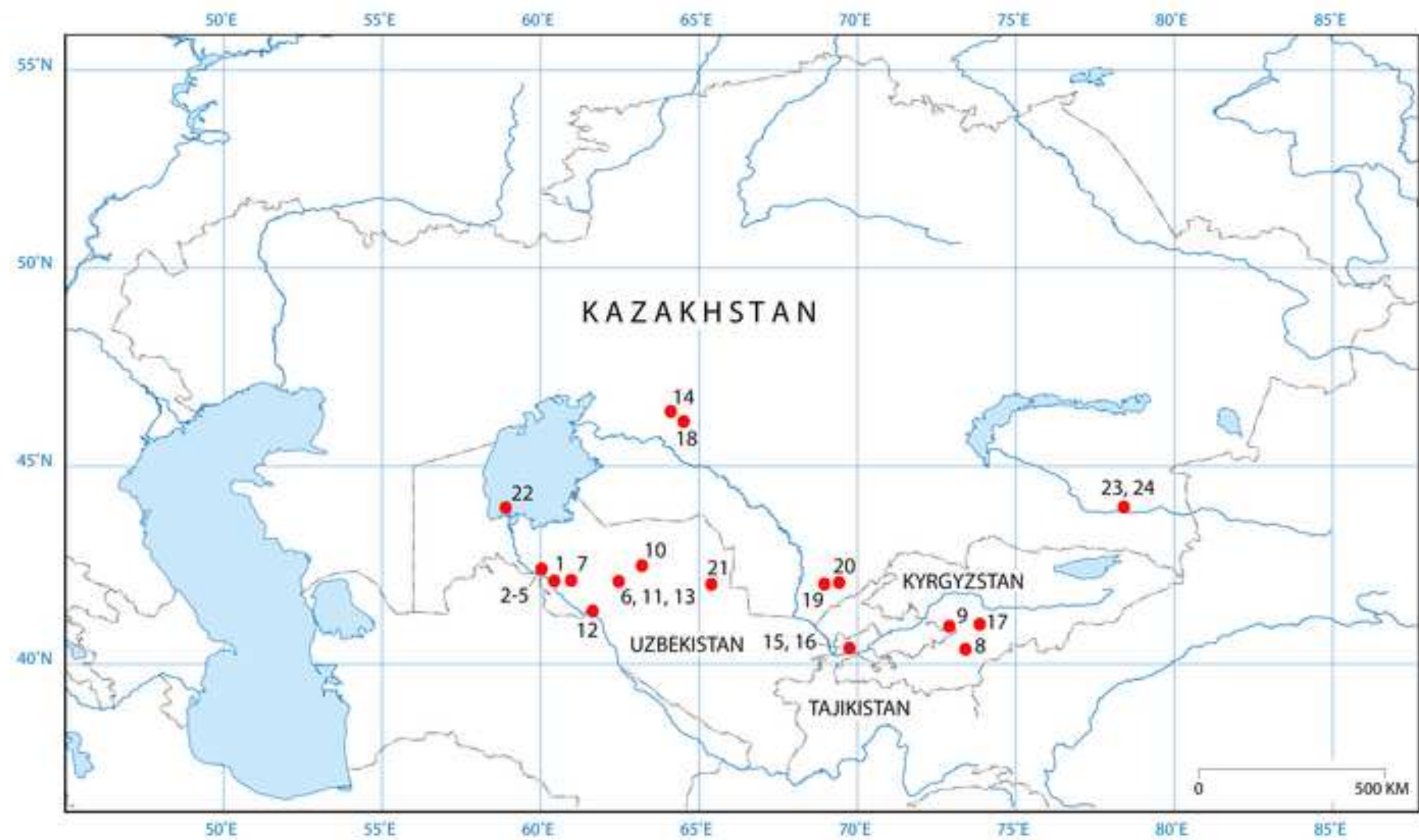



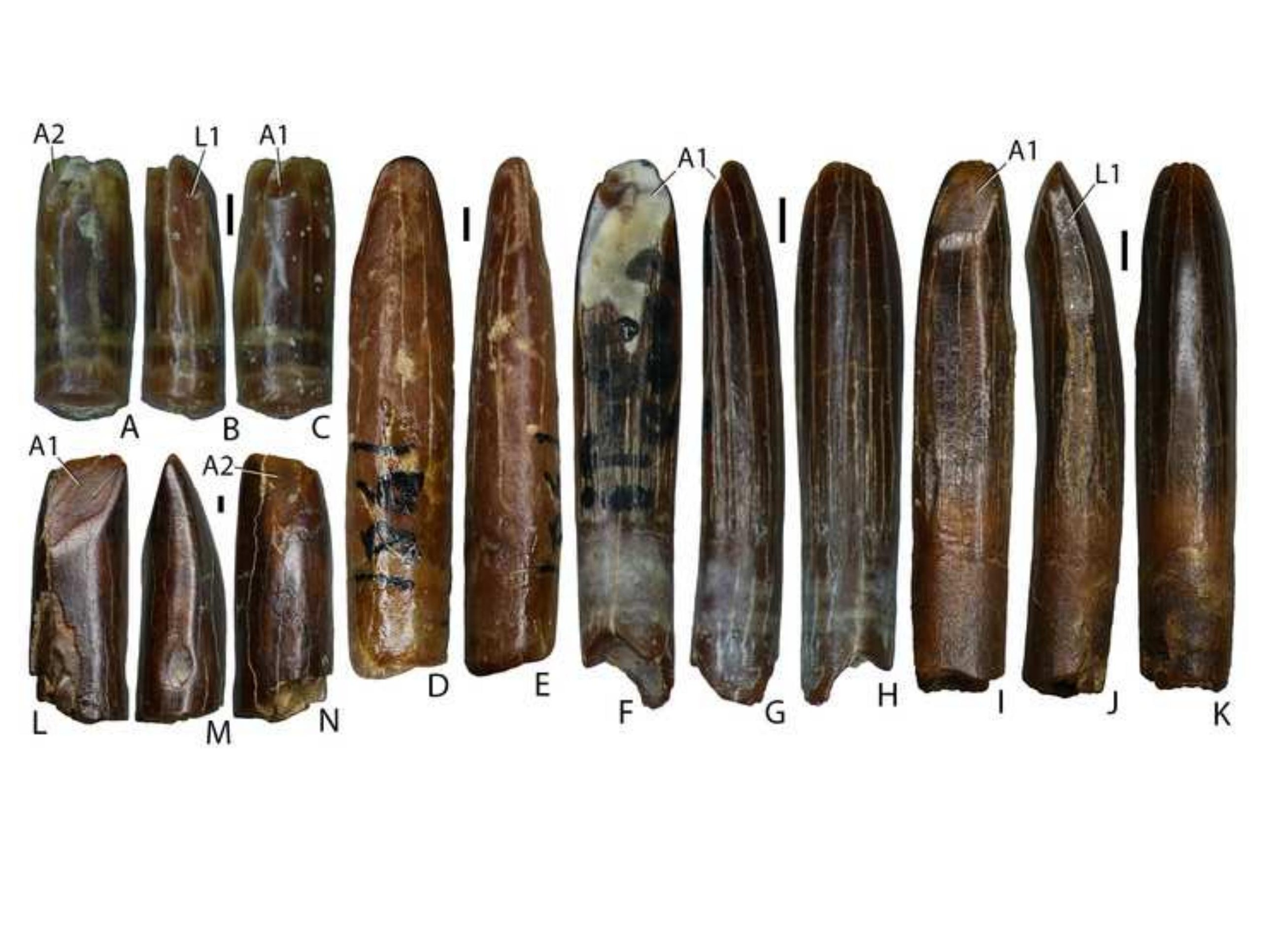

$$
\text { u }
$$

.



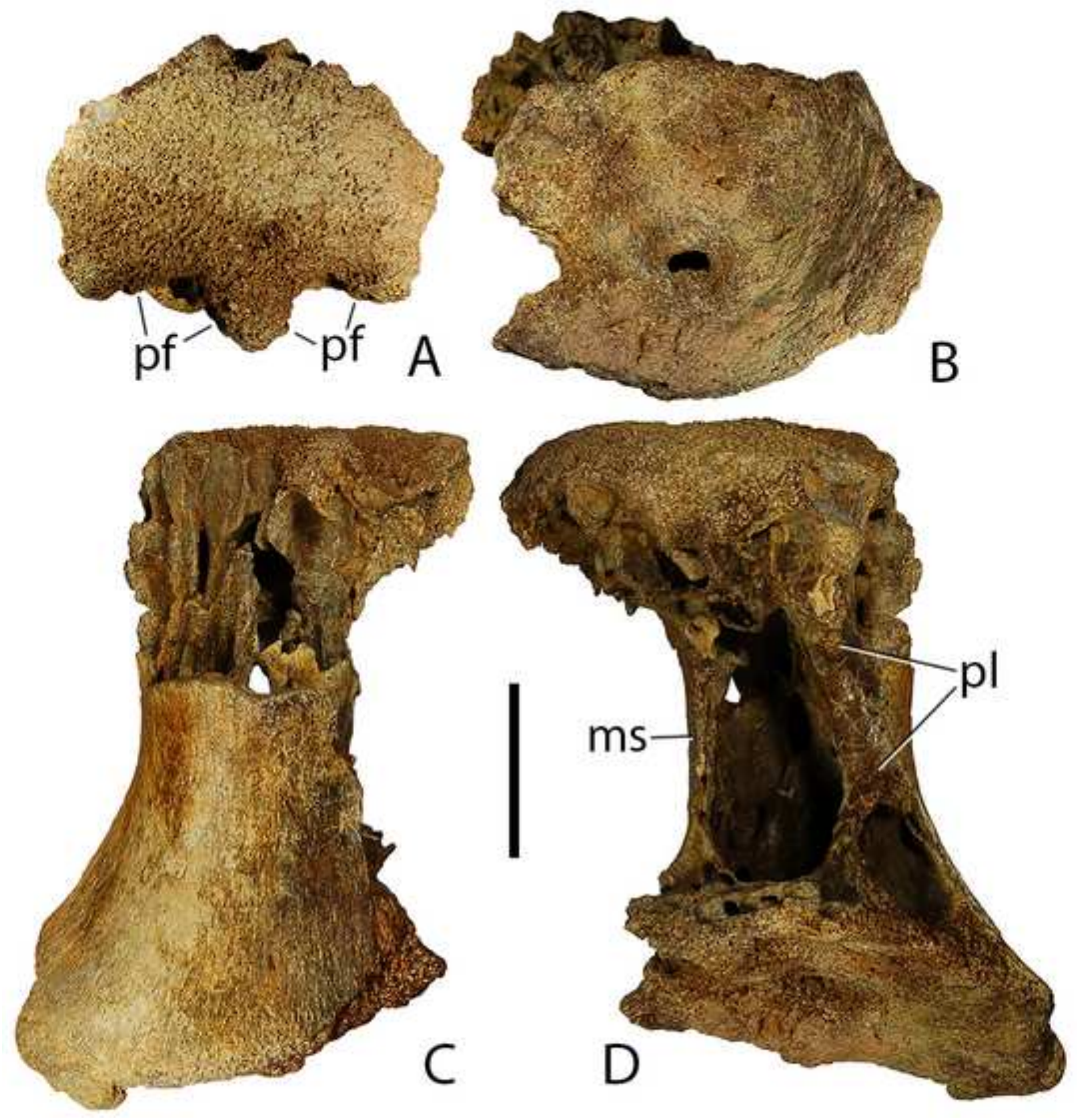

Figure 4 

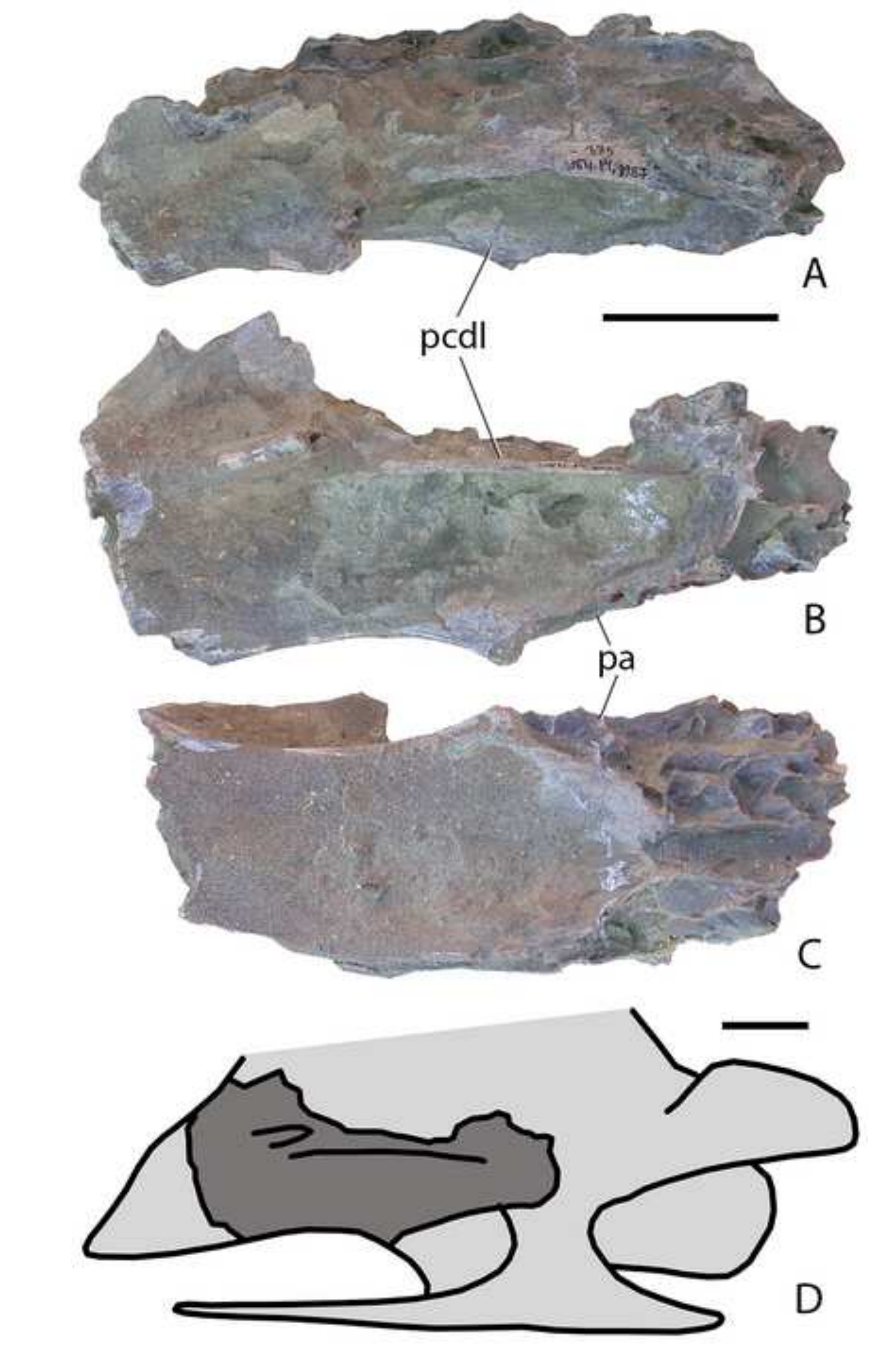

Figure 5

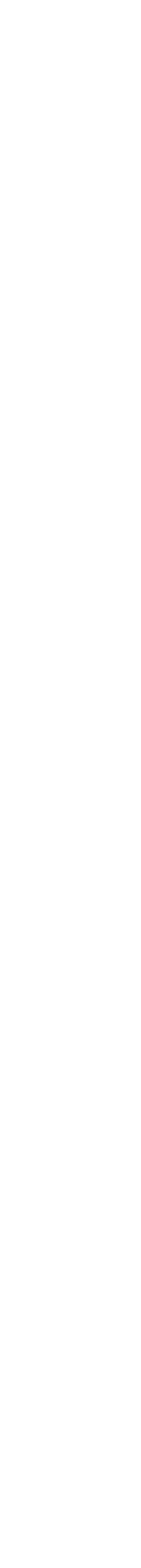

Figure 5

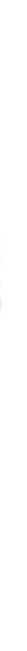

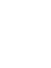
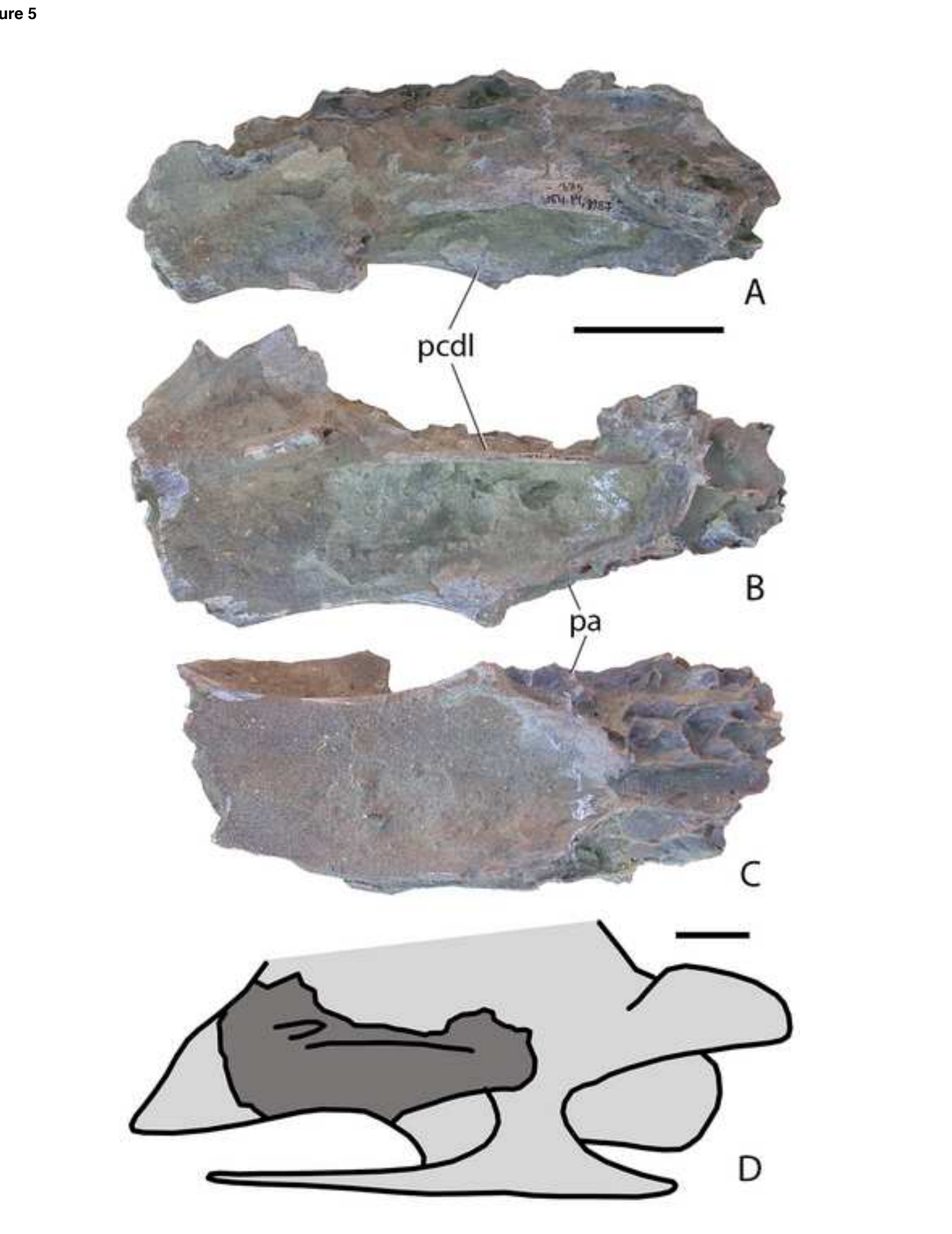

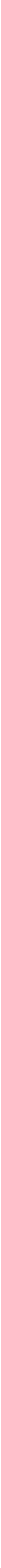

$$
\text { . }
$$

Figure 6

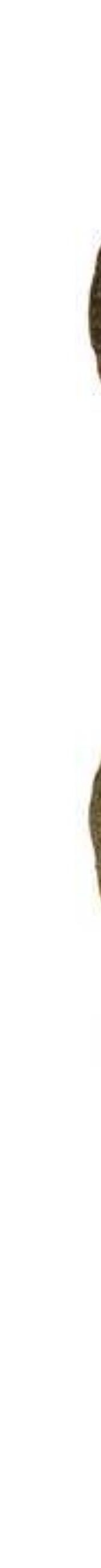



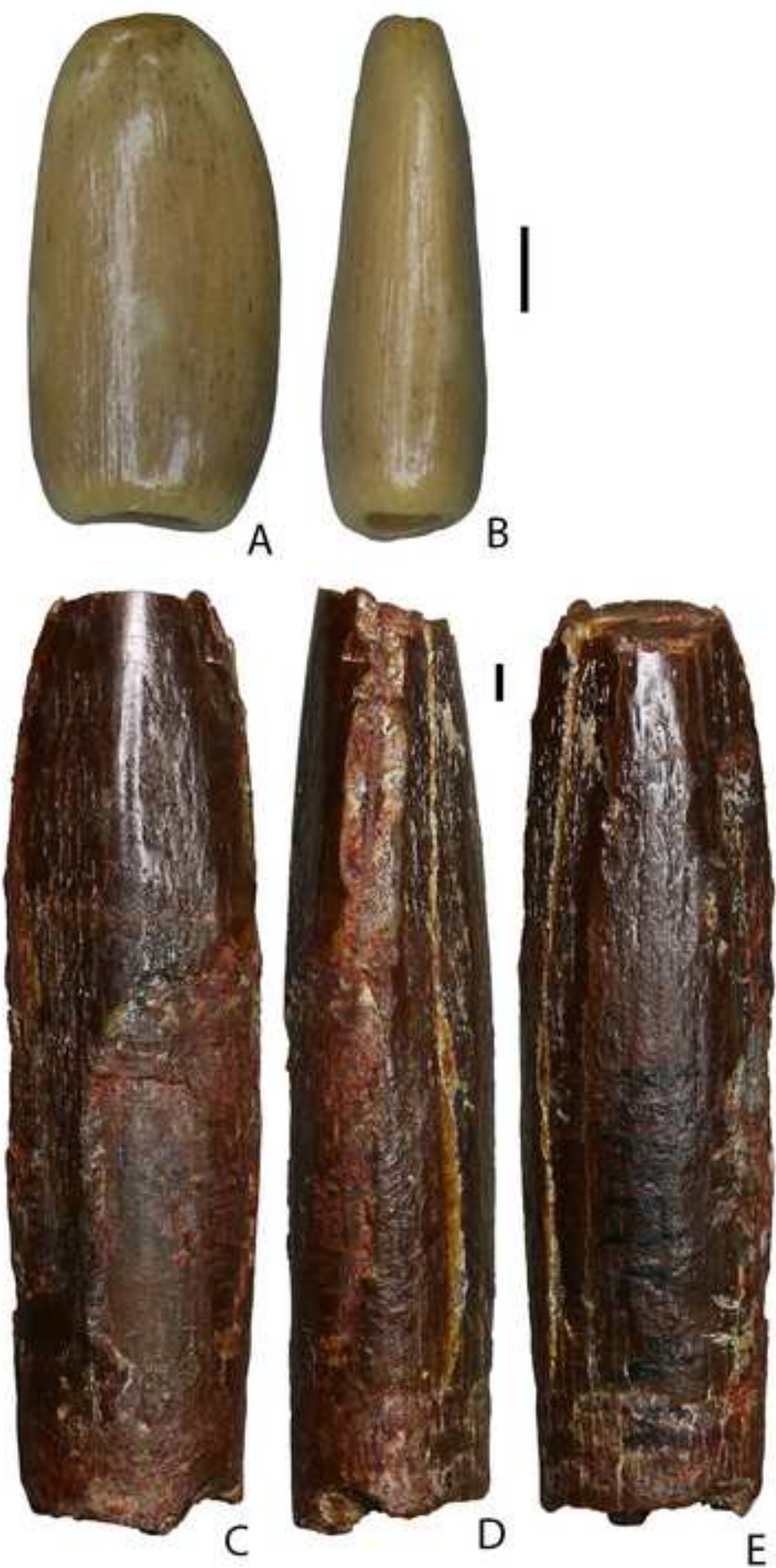

E 


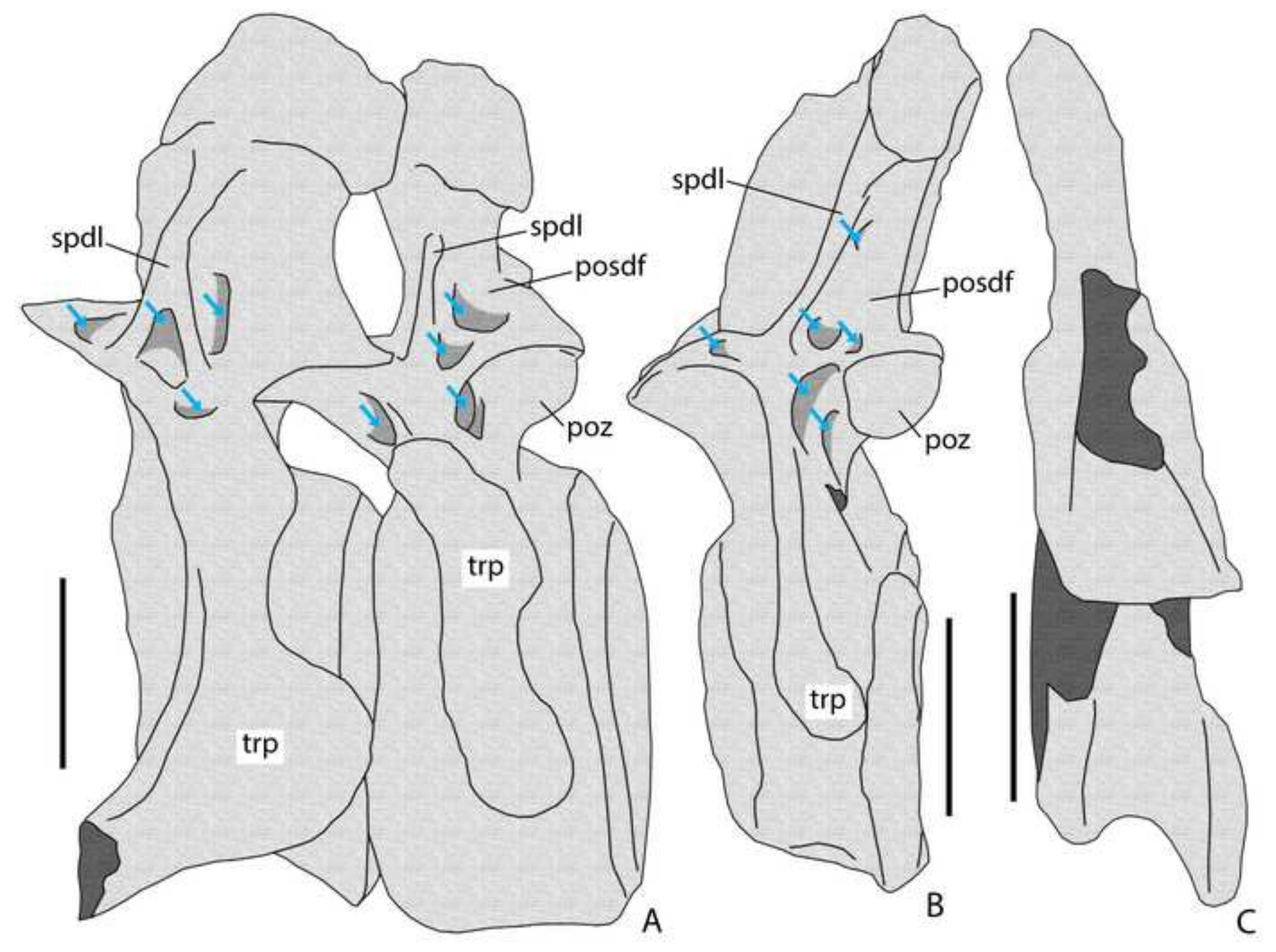




\begin{tabular}{|cccccccc|cc|c|c|}
120 & 115 & 110 & 105 & 100 & 95 & 90 & 85 & 80 & 75 & 70 & Ma \\
\hline Aptian & Albian & Cen. & Tur. & Con. & S. & Campanian & Ma. \\
\hline
\end{tabular}

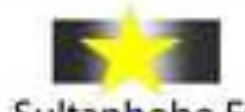

Sultanbobo Fm
Gobi, Mongolia

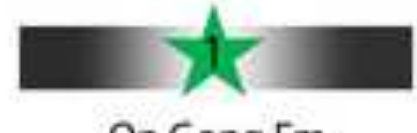

On Gong Fm

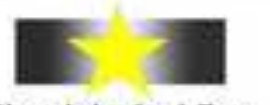

중

Khodzhakul Fm Bi. Fm Aitym Fm Kynyr Fm

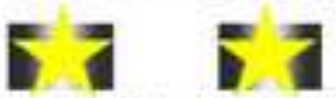

Zhirkindek Fm Bostobe Fm

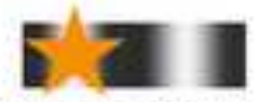

Syuk Syuk Fm Darbasa Fm

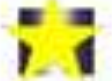

Yalovach Fm

Sharikhan $\mathrm{Fm}$
Kyzylkum, Uzbekistan

W. Kazakhstan

S. Kazakhstan

Fergana Basin

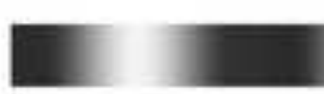

$=$
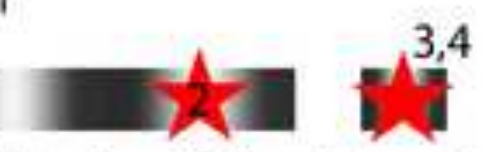

LBS Fm UBS Fm Djadokhta Fm BG Fm Nemegt Fm

Gobi, Nei Mongol

Iren Dabasu Fm Bayan Mandahu Fm

Xichuan Basin, Henan, China

Ruyang Basin, Henan, China

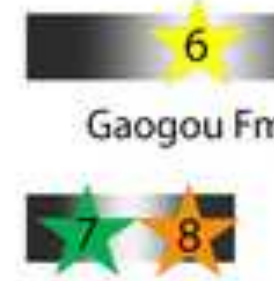

Mangchuan Fm
Majiacun Fm

Fangyan $\mathrm{Fm}$
1, Mongolosaurus

2, Quaesitosaurus

3 , Nemegtosaurus

4, Opisthocoelicaudia

5 , Sonidosaurus

6, Baotianmansaurus

7. Ruyangosaurus

8, Xianshanosaurus

9, Jiangshanosaurus

10, Dongyangosaurus 
Table 1. List of Cretaceous titanosaurian or possibly titanosaurian taxa from Eastern Asia. The age estimate in most cases follows that of Mannion et al. (2013).

\begin{tabular}{|c|c|c|c|c|}
\hline Taxon & $\begin{array}{l}\text { Formation / } \\
\text { Region }\end{array}$ & Age & Material & Reference \\
\hline $\begin{array}{l}\text { Baotianmansaurus } \\
\text { henanensis }\end{array}$ & $\begin{array}{l}\text { Gaogou Fm / } \\
\text { Henan, China }\end{array}$ & $\begin{array}{l}\text { Cenomanian- } \\
\text { Turonian }\end{array}$ & $\begin{array}{l}\text { Vertebrae, ribs, } \\
\text { scapula } \\
\text { fragment }\end{array}$ & $\begin{array}{l}\text { Zhang et al., } \\
2009\end{array}$ \\
\hline $\begin{array}{l}\text { Borealosaurus } \\
\text { wimani }\end{array}$ & $\begin{array}{l}\text { Sunjiawan Fm / } \\
\text { Liaoning, China }\end{array}$ & $\begin{array}{l}\text { Cenomanian- } \\
\text { Turonian }\end{array}$ & $\begin{array}{l}\text { Caudal } \\
\text { vertebrae, } \\
\text { tooth, humerus }\end{array}$ & You et al., 2004 \\
\hline $\begin{array}{l}\text { Daxiatitan } \\
\text { binglingi }\end{array}$ & $\begin{array}{l}\text { Hekou Group / } \\
\text { Gansu, China }\end{array}$ & Aptian & $\begin{array}{l}\text { Partial } \\
\text { postcranial } \\
\text { skeleton } \\
\end{array}$ & You et al., 2008 \\
\hline $\begin{array}{l}\text { Dongyangosaurus } \\
\text { sinensis }\end{array}$ & $\begin{array}{l}\text { Fangyan Fm/ } \\
\text { Zhejiang, China }\end{array}$ & $\begin{array}{l}\text { Cenomanian- } \\
\text { Santonian }\end{array}$ & $\begin{array}{l}\text { Partial } \\
\text { postcranial } \\
\text { skeleton } \\
\end{array}$ & Lü et al., 2008 \\
\hline $\begin{array}{l}\text { Jiangshanosaurus } \\
\text { lixianensis }\end{array}$ & $\begin{array}{l}\text { Jinhua Fm / } \\
\text { Zhejiang, China }\end{array}$ & Albian & $\begin{array}{l}\text { Partial } \\
\text { postcranial } \\
\text { skeleton } \\
\end{array}$ & Tang et al., 2001 \\
\hline $\begin{array}{l}\text { Mongolosaurus } \\
\text { haplodon }\end{array}$ & $\begin{array}{l}\text { On Gong Fm / } \\
\text { Mongolia }\end{array}$ & Aptian-Albian & $\begin{array}{l}\text { Isolated teeth, } \\
\text { basioccipital, } \\
\text { cervical } \\
\text { vertebrae }\end{array}$ & $\begin{array}{l}\text { Gilmore, 1933; } \\
\text { Mannion, } 2011\end{array}$ \\
\hline $\begin{array}{l}\text { Nemegtosaurus } \\
\text { mongoliensis }\end{array}$ & $\begin{array}{l}\text { Nemegt Fm / } \\
\text { Mongolia }\end{array}$ & Maastrichtian & Skull & $\begin{array}{l}\text { Nowinski, 1971; } \\
\text { Wilson, 2005b }\end{array}$ \\
\hline $\begin{array}{l}\text { Opisthocoelicaudia } \\
\text { skarzynskii }\end{array}$ & $\begin{array}{l}\text { Nemegt Fm / } \\
\text { Mongolia }\end{array}$ & Maastrichtian & $\begin{array}{l}\text { Postcranial } \\
\text { skeleton }\end{array}$ & $\begin{array}{l}\text { Borsuk- } \\
\text { Białynicka, } 1977\end{array}$ \\
\hline $\begin{array}{l}\text { Qingxiusaurus } \\
\text { youjiangensis }\end{array}$ & $\begin{array}{l}\text { Red beds / } \\
\text { Guangxi, China }\end{array}$ & Late Cretaceous & $\begin{array}{l}\text { Caudal vertebra } \\
\text { neural spine, } \\
\text { humerus, } \\
\text { sternal plate }\end{array}$ & Mo et al., 2008 \\
\hline $\begin{array}{l}\text { Quaesitosaurus } \\
\text { orientalis }\end{array}$ & $\begin{array}{l}\text { Barun Goyot } \\
\text { Fm/ Mongolia }\end{array}$ & Campanian & Skull & $\begin{array}{l}\text { Kurzanov and } \\
\text { Bannikov, } 1983\end{array}$ \\
\hline $\begin{array}{l}\text { Ruyangosaurus } \\
\text { giganteus }\end{array}$ & $\begin{array}{l}\text { Mangchuan Fm/ } \\
\text { Henan, China }\end{array}$ & Cenomanian & $\begin{array}{l}\text { Vertebrae and } \\
\text { limb bones }\end{array}$ & Lü et al., 2009a \\
\hline $\begin{array}{l}\text { Sonidosaurus } \\
\text { saihangaobiensis }\end{array}$ & $\begin{array}{l}\text { Iren Dabasu Fm/ } \\
\text { Nei Mongol, } \\
\text { China }\end{array}$ & $\begin{array}{l}\text { Turonian - } \\
\text { Santonian }\end{array}$ & $\begin{array}{l}\text { Partial } \\
\text { postcranial } \\
\text { skeleton } \\
\end{array}$ & Xu et al., 2006 \\
\hline $\begin{array}{l}\text { Yongjinglong } \\
\text { datangi }\end{array}$ & $\begin{array}{l}\text { Hekou Group / } \\
\text { Gansu, China }\end{array}$ & Early Cretaceous & $\begin{array}{l}\text { Partial } \\
\text { postcranial } \\
\text { skeleton } \\
\end{array}$ & Li et al., 2014 \\
\hline $\begin{array}{l}\text { Xianshanosaurus } \\
\text { shijiagouensis }\end{array}$ & $\begin{array}{l}\text { Mangchuan Fm/ } \\
\text { Henan, China }\end{array}$ & $\begin{array}{l}\text { Cenomanian- } \\
\text { Santonian }\end{array}$ & $\begin{array}{l}\text { Partial } \\
\text { postcranial } \\
\text { skeleton }\end{array}$ & Lü et al., 2009b \\
\hline
\end{tabular}


Table 2. Phylogenetic position of the sauropod taxa listed in Table 1. Abbreviations: NLT, non-

lithostrotian titanosaurian; NSL, non-saltasaurid lithostrotian; NTS, non-titanosaurian somphospondylan.

\begin{tabular}{|l|l|l|l|}
\hline Taxon & D'Emic (2012) & Mannion et al. (2013) & This study \\
\hline Baotianmansaurus & Euhelopodidae & Saltasauridae or NLT & NLT \\
\hline Borealosaurus & Not available & ?Titanosauria & NLT \\
\hline Daxiatitan & Euhelopodidae & NLT & NSL \\
\hline Dongyangosaurus & Euhelopodidae & Saltasauridae & NLT \\
\hline Jiangshanosaurus & Saltasauridae & Saltasauridae & NLT \\
\hline Mongolosaurus & NTS & Lithostrotia or NLT & NTS \\
\hline Nemegtosaurus & Not available & Derived titanosaurian & Saltasauridae \\
\hline Opisthocoelicaudia* & Saltasauridae & Saltasauridae & Saltasauridae \\
\hline Quaesitosaurus & Not available & Derived titanosaurian & Saltasauridae \\
\hline Qingxiusaurus & Lithostrotia & Derived titanosaurian & Saltasauridae \\
\hline Ruyangosaurus & NTS & NTS or NLT & NTS \\
\hline Sonidosaurus & NTS & Derived titanosaurian & NSL \\
\hline Yongjinglong & Not available & Not available & NLT \\
\hline Xianshanosaurus & Lithostrotia & NLT & NSL \\
\hline
\end{tabular}

*Clade specifier for Saltasauridae. 